\title{
Why are the Performances of Business Groups Different? A Case Study of Formosa Plastics Group and Far Eastern Group
}

\author{
Yu-Wei $\operatorname{Lan}^{1} \Varangle$ (D) \\ Dan Lin² (D) \\ Lu Lin ${ }^{3}$ \\ ${ }^{2}$ Department of Banking and Finance, Takming University of Science and Technology, Taiwan \\ Email:ywlan@takming.edu.two Tel: 8862-26585801 \\ ${ }^{3}$ Department of Public Finance and Taxation, Takming University of Science and Technology, Taiwan \\ 'Email: suzannelin@takming.edu.tw Tel: 8862-26585801
}

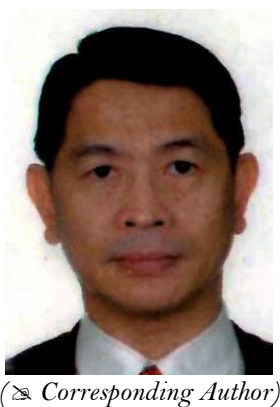

\section{Abstract}

This study examines the difference in performances of two business groups, Formosa Plastics Group and Far Eastern Group, under the impact of financial tsunami (2007.10.29 2017.8.10). The aim of this study is to help investors understand the operating model of business groups and use the herding effect to enhance the trading performance in financial markets. The empirical evidence shows that for the Formosa Plastics Group, the news impact curve (based on EGARCH model) including the leading company is flatter when the news impact is less than zero (that is, negative news impact) than the news impact curve excluding the leading company. In contrast, the news impact curve of the Far Eastern Group is steeper when the leading company is included. Moreover, when the leading company is included as an endogeneous variable in the model as a filter for the program trading simulation, results show that investors can profit from the Formosa Plastics Group. Therefore, business groups that include the leading company have lower risks. It is beneficial to the stability of the market trading by incorporating the leverage effect of the leading company in business groups. On the contrary, the leading company of the Far Eastern Group does not have such an effect. The absolute profits and the increment of performance are both lower than that of the Formosa Plastics Group. The results suggest that the diversification strategy of Far Eastern Group is worse than the vertical integration strategy of the Formosa Plastics Group. The implication is that investors should carefully choose the business group for investment if they are to utilize the herding effect in investment.

Keywords: Family business, EGARCH, Herd effect, Granger causality test, Symmetric trading.

Citation | Yu-Wei Lan; Dan Lin; Lu Lin (2017). Why are the Performances of Business Groups Different? A Case Study of Formosa Plastics Group and Far Eastern Group. Asian Journal of Economics and Empirical Research, 4(2): 106-120. History:

Received: 18 October 2017

Revised: 8 Novenber 2017

Revised. 8 November 2017

Accepted: 13 November 2017

Published: 16 November 2017

Licensed: This work is licensed under a Creative Commons Attribution 3.0 License (cc) E E

Publisher:Asian Online Journal Publishing Group
Contribution/Acknowledgement: All authors contributed to the conception and design of the study.

Funding: This study received no specific financial support.

Competing Interests: The authors declare that they have no conflict of interests.

Transparency: The authors confirm that the manuscript is an honest, accurate, and transparent account of the study was reported; that no vital features of the study have been omitted; and that any discrepancies from the features of the study have been omitte
study as planned have been explained.

Ethical: This study follows all ethical practices during writing.

\section{Contents}

1. Introduction

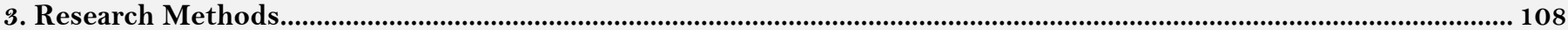

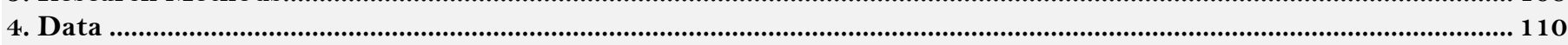

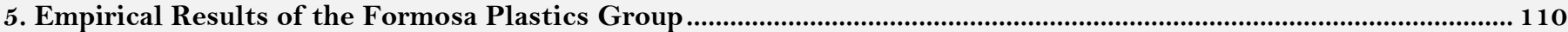

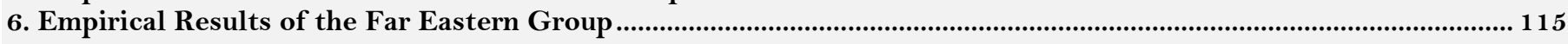

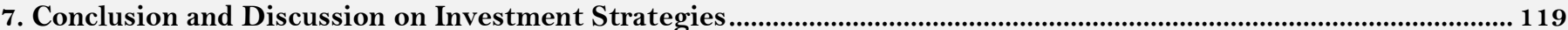

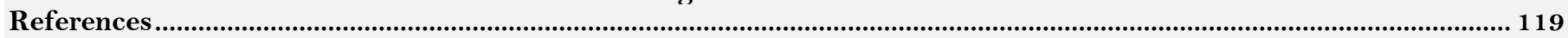

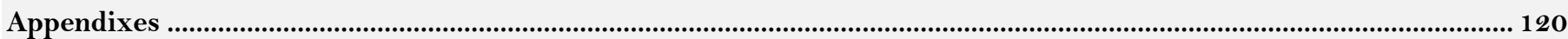




\section{Introduction}

All business groups around the world are formed based on independent companies. Businesses that have certain resources (such as entrepreneurial skills and technical skills) are likely to profit from other businesses. Alternatively, businesses can lower the risks through diversifications. When there is a lack of basic infrastructure or weak social economic and legal systems, the cost of transactions between buyers and sellers can be expensive. It may be cheaper and more efficient to trade within the business group. Some business groups may even use this method to monopolize the market. Therefore, some business groups attempt to diversify by connecting several unrelated businesses through formal stock holdings or informal family networks. Some other business groups operate by focusing on their industry through vertical integrations. ${ }^{1}$

Two issues arisen from this complex organizational style. The first treats business groups as a diversified entity and analyzed the relationship between this feature, industrial organization and financing problems. Business groups can control their related enterprises through internal trading and capital. Currently, $40 \%$ of the top 500 companies around the world are controlled by families. Families tend to use pyramid holdings to maintain their controls. Finkelstein (1992) finds that family members have higher commitments to their businesses and pay attention to the businesses' long-term developments. By extending their tenure to consolidate their power, the transaction costs in business management can be lowered. Johannisson and Huse (2000) also support the view that the cohesion of the founder to the enterprise can help increase the operating efficiency of the family business group. The second issue is raised by the corporate governance survey of Shleifer and Vishny (1997) and the following work by La Porta et al. (1997;1998). La Porta et al. (1999) examine the top 20 companies around 27 countries and find that the ultimate holders of business groups will expropriate small shareholders and hollowed out the companies through pyramid holdings. Jain and Kini (2000) argue that if there are too many family members on the board of directors, this is likely to limit the resource network of the companies. Baek and Kang (2004) also find that controlling shareholders of business groups often use internal trading and asset restructuring to transfer the companies' resources to become their property. Therefore, understanding this complex operating model is a great challenge to investors. The aim of this research is to directly examine the stock performance of business groups in order to search for better investment opportunities. The prime job is then to understand the relationship between the operating strategy of business groups and their stock performance.

The Formosa Plastics Group was first established in 1954 as a plastics company. After more than 50 years of hard work, the Formosa Plastics Group now have more than hundreds of related enterprises including Formosa Plastics, Nan Ya, Formosa Chemicals \& Fibre, Formosa Petrochemicals, Formosa Ha Tinh Steel and etc. These companies are spread out in Taiwan, USA, China, Vietnam, Philippine, and Indonesia. The Group is also committed to education and medical care by establishing a hospital and universities. The Formosa Plastics Group is the largest private company in Taiwan. To follow the spirit of a separation of ownership and control, the founders of Formosa Plastics Group established an Administration Centre which is for the Group's family members and an Executive Centre which is led by a professional manager. This structure was executed in June 2017. ${ }^{2}$

The second business group examined in this study is the Far Eastern Group, which was first established in 1937 in China. The company started its textile business in 1953 in Taiwan. It then diversified to other businesses such as petrochemical energy, cement building materials, department store retailing, financial services, land \& sea transportation, communication networks, and tourism hotels. The business group has more than 200 related companies. Of which, eight companies are listed in Taiwan, and one company, Asia Cement, is listed in Hong Kong. Far Eastern Group is the third largest business group in Taiwan and is a model of diversified companies in Taiwan. ${ }^{3}$

In 2014, the total market values of Formosa Plastics Group and Far Eastern Group were $\$ 2680.8$ billion and $\$ 679$ billion, respectively. However, in July 2017, the market value of Formosa Plastics Group increased to \$3032.6 billion while the market value of Far Eastern Group decreased to $\$ 572.3$ billion. One common feature of the business group is the cross holdings between related businesses. Therefore, if the performance of related companies changes, the investment profits of the whole business group will be affected. When the benefit of vertical integration gradually reveals, the after tax net profits of Formosa Plastics group increased by $43.11 \%$ in 2016 . In contrast, as the economy becomes more volatile, diversified operations will encounter greater challenges. Hence, the after tax net profits of Far Eastern Group reduced by $19.44 \%$ in 2016. ${ }^{4}$ Therefore, this study proposes a program trading investment strategy based on behavioral finance theory to help individual investors trade the stocks of family businesses. The organization of the paper is as follows.

Section 2 is the literature review. Section 3 discusses the Granger causality, EGARCH model and the estimation method for program trading. Section 4 describes that data source. Section 5 and 6 presents that empirical results and analyses for the Formosa Plastics Group and the Far Eastern Group, respectively. Finally, the conclusion is presented in the last section.

\section{Literature Review}

Both researches by Bachelier (1900) and Samulson (1965) argue that the stock prices are unpredictable. Fama (1965) also suggests that the trend in stock price is random. Fama (1970) then proposes an efficient market

According to Khanna and Yishay (2015). diversification is measured by two-digit ISIC industry classifications. The degree of vertical integration of a business group $(\mathrm{x}, \mathrm{y})$ is measured by the degree of investment in each other's businesses. The petrochemical system of Formosa Plastics Group basically mimicked Japan's regional petrochemical industry connection model of Isard (1951). in Taiwan Tsai (1997). Based on the investment input, the correlation coefficients of petrochemical industry businesses are 7.72 for Formosa Plastics Group and 6.71 for Far Eastern Group (see Appendix 1). As for the degree of diversification, petrochemical industry businesses are 7.72 for Formosa Plastics Group and 6.71 for Far Eastern Group (see Appendix 1). As for the degree of diversification,
as this study does not use individual company's data, there is no need to calculate the weighted entropy index of Palepu (1985). The Formosa Plastics Group has nine companies across four industries (0.44) and the Far Eastern Group has eight companies across seven industries (0.87). Therefore, comparing the two business groups, this study defines the former as having a vertical integration and the later as having a diversification.

${ }^{2}$ Refer to United Daily News (2017-05-18), "Family Members of Formosa Plastics Group Withdraw from Executive Centre from June." https://udn.com/news/story/11142/2471011. Unique Business Weekly (Issue 1011)(2017-10-23), "Profits Tracing by Formosa Plastics Group".

${ }^{3}$ Refer to http://www.feg.com.tw/tw/business/important.aspx and https://zh.wikipedia.org/

${ }^{4}$ Refer to Wealth Magazine (2017-07-27), "Why does the difference in market values of the two biggest business groups grow larger? Vertical integration of Formosa Plastics Group versus the diversification of Far Eastern Group." http://www.wealth.com.tw
For 
hypothesis $(\mathrm{EMH})$ by suggesting that all participating investors in the market are rational, are aimed to maximize their utility and are able to make unbiased estimates based on all available information. As the stock prices follow random walks and investors arbitrage, no abnormal profits exist in the market.

More and more evidence reveal market anomalies after 1980s, showing "limited rational behavior" as suggested by behavioral finance. Shiller (1981) finds that the results of NYSE listed companies are completely differently from Sharp's asset pricing model. The return of higher risk stocks is lower than the theoretical prediction. The volatility of stock prices cannot be predicted by the discounted present value of premium. Banz (1981) finds that the monthly returns of 50 smallest market cap companies are $1 \%$ higher than the returns of 50 largest market cap companies. Lakonishok and Smidt (1988) also find season effect in US stock markets and Cadsby (1989) reports calendar effect in Canadian stock market.

As for the herding behavior, Shiller (1979) finds over reaction in speculative asset prices. Investors often trade based on noise trading and have positive feedback behavior. Economists propose reasons from the perspectives of information asymmetry, reputation, return and limited rational behavior. From the information cascade point of view, Bikhchandani et al. (1992) argue that when investors omit private information and simply mimic others, this has great impacts on the markets and is likely to cause a domino effect. Scharfstein and Stein (1990) from the reputation viewpoint suggest that by mimicking other managers' investment portfolio, managers can save the cost of information search. They can also shirk responsibility and have less regrets if making investment losses. Maug and Naik (2013) from the return viewpoint argue that due to moral hazard and inverse selection, having optimal contracts between managers and the owner that link remuneration with performance is the best solution. Managers are encouraged to collect information and therefore avoid moral hazard. Also, we can separate good and bad fund managers and avoid inverse selections. Therefore, fund managers tend to have herd behavior.

The empirical evidence by Lakonishok et al. (1992) shows herding behavior among fund managers when they trade small companies' stocks. Froot et al. (1993) also find herding behavior among financial analysts as they use similar information sources, economic models, investment portfolios and hedging strategies. Christie and Huang (1995) examine the measures for herding effect, stock market returns and dispersion in investment portfolio returns. They find that the smaller the dispersion, the more prominent the herding effect. Wermers (1999) studies the herding behavior of mutual funds between 1975 and 1994 and finds that herding behavior of mutual funds is rational as it can fasten the absorption of information in stock prices and help stabilize the market. However, Kim and Wei (2002) examine the herding behavior of QFIIs in Korea and find that it can increase volatilities in the emerging markets.

Moreover, Alanyali et al. (2013) find a positive relationship between the numbers of issues mentioned in Financial Times and daily trading volume. This shows a close relation between changes in financial markets and financial news. Cipriani and Guarino (2014) builds a herding information model and shows that the herding behavior is rational when there is information uncertainty. Herding behavior also typically happens on certain days. On average, there is a $2 \%$ of herding buyers and $4 \%$ of herding sellers. Balcilar and Demirer (2015) examine Turkish investors and find that apart from industrial departments, US and market related factors cause a transformation in the market, causing herding behavior in all market departments.

Furthermore, since the financial tsunami in 2007, Exchange Traded Funds (ETFs) become a popular passive investment tool among retail and professional investors due to its low transaction costs. However, Ben-David et al. (2017) find that although ETFs can help with price discovery, they can inject non-fundamental volatility to market prices and affect the correlation structure of returns. During the events of market stress, ETFs will affect the liquidity of the underlying portfolios and are likely to cause a herding effect of a sudden drop in markets. Taiwan 50 ETF (0050), issued in 2005, is currently the largest ETF in terms of size (\$58.6 billion) in Taiwan. Taiwan Mid 100 (0051) was issued in 2007 . The fund size is $\$ 380$ million. This study uses 0050 and 0051 as filters in the experiments to examine the herding behavior of following large business groups.

This research studies the herding behavior from the business group viewpoint. Past studies typically measure the degree of dispersion. In contrast, this study proposes a new testing method by utilizing quantitative models and optimal program trading to test the following two hypotheses. The first hypothesis is that including the price information of leading company should lower the impact of selling news on investors. The first hypothesis is tested in two steps with an attempt to find a stabilized investment strategy for trading family business groups' stocks. The second hypothesis tests if the trading performance can be enhanced using technical analyzes by including the leading company of the family business group. The second hypothesis can also indirectly prove the existence of herding behavior in business groups.

\section{Research Methods}

\subsection{Theoretical Models and Estimation Methods of VAR and Granger Causality}

The traditional test of herding effect measures the degree of dispersion. However, this method requires internal trading data. Due the data collection problem, this study uses econometric methods to examine herding effect, the testing methods are as follows: (1) examining if unit roots exist; (2) testing if the model has co-integration; (3) testing the causal relationship between variables in the model; (4) using the variable that has the strongest causal relationship as the leading company and using program trading experiments to test if the herding effect exists.

Engle and Granger (1987) suggest that one important function of VAR model is to use co-integration relationship as a restriction in VAR model to examine long-term dynamic relationships between variables in the model. Later, Johansen and Juselius (1988) and Johansen (1991) propose a co-integration test for multi-variables, $\operatorname{VAR}(\mathrm{P})$, which is outlined below:

$$
Y_{t}=C+\Pi_{1} Y_{t-1}+\Pi_{2} Y_{t-2}+\ldots+\Pi_{p} Y_{t-p}+U_{t}
$$

where $Y_{t}=\left(y_{1 t} \ldots y_{n t}\right)^{\prime}$ and hypothesize $Y_{t} \sim I(1)$.

After transformation, $\operatorname{VAR}(\mathrm{P})$ in Equation (1) can be represented as the following:

$$
\Delta Y_{t}=C+\Gamma_{1} \Delta Y_{t-1}+\Gamma_{2} Y_{t-2}+\ldots+\Gamma_{p-1} \Delta Y_{t-p+1}+\Omega Y_{t-p}+U
$$


where $\Gamma_{i}=-I+\Pi_{1}+\ldots+\Pi_{i}, i=1 \ldots p$, and $\Omega=-I+\Pi_{1}+\ldots+\Pi_{p}$

In Equation (2), apart from $\Omega Y_{t-p}$, all other variables are stationary. Therefore, similar to $\operatorname{VAR}(1)$, the compressed matrix $\Omega$ before vector $Y_{t-p}$ can be used to test the co-integration relationship between variables. If the rank of coefficient matrix $\Omega$ is $r k \Omega=r<n$, then there exists an adjacency matrix $(n \times r) \alpha$ and $\beta$. As their ranks are both $\mathrm{r}$, this means $\Omega=\alpha \beta^{\prime}$ and $\beta^{\prime} T_{t-p}$ is stationary with $\beta^{\prime} T_{t-p} \sim I(0) . \beta$ is a co-integrated parameter matrix that reflects the long-term relationship between variables. $\alpha$ is an adjusted coefficient matrix that reflects the shortterm imbalance adjustment of this period's variable from last period. One method of co-integration test proposed by Johansen is the trace test, which can be calculated as follows:

$$
L R_{r}=-T^{*} \sum_{i=r+1}^{n} \operatorname{Ln}\left(1-\lambda_{i}\right)
$$

where $\lambda_{i}$ is the eigenvalue of a certain matrix arisen from the testing process.

The second method is to use the maximum eigenvalue test, which can is calculated as follows:

$$
L R_{\max }=-T^{*} \operatorname{Ln}\left(1-\lambda_{r}\right)
$$

where $\lambda_{i}$ is the maximum eigenvalue.

Based on the feature of time series (with or without trend and linearity or secondary type) and the form of cointegration equation (CE) and VAR, Johansen co-integration test can be checked one by one. ${ }^{5}$

\subsection{Theoretical Model and Estimation Method of EGARCH}

Past research often uses GARCH models to test stock market volatility. However, as many time series data in the financial market do not have normal distribution or do not meet the traditional requirement of homoscedasticity and have fat tails and volatility cluster, Bollerslev (1986) builds a GARCH model based on ARCH. It has become a common method of testing the volatility in stock market returns. The econometrists continue to modify the GARCH model. Nelson (1991) then proposes an EGARCH model. Compared to GARCH models which have restrictions on coefficients, EGARCH $(1,1)$ can give more appropriate conditional variance and better reflect the volatility in market returns. The EGARCH model is provided below:

Mean equation: $y_{t}=\gamma x_{t}+u_{t}$.

Conditional variance:

$$
\ln \left(\sigma_{t}^{2}\right)=\omega+\alpha\left|\frac{u_{t-1}}{\sigma_{t-1}}\right|+\gamma \frac{u_{t-1}}{\sigma_{t-1}}+\beta \ln \left(\sigma_{t-1}^{2}\right)
$$

Moreover, to test the effect on investors when the leading company's stock price is or is not included, this paper adopts the method used in Lan et al. (2014;2017) and tests for the difference in $\gamma$ coefficients. The $t$ statistics can be calculated as follows:

$$
t=\left(\left|\gamma_{2}\right|-\left|\gamma_{1}\right|\right) / \sqrt{\frac{\hat{\sigma}_{1}^{2}}{n_{1}}+\frac{\hat{\sigma}_{2}^{2}}{n_{2}}}
$$

where

$\gamma_{1}, \gamma_{2}$ are the $\gamma$ coefficient for including (or excluding) the leading company's stock prices.

$\hat{\sigma}_{1}^{2}$ and $\hat{\sigma}_{2}^{2}$ are the covariance of $\gamma$.

$n_{\imath}$ and $n_{2}$ represent the sample size.

If the latter is greater than the former and there is a significant difference in coefficients, this suggests that excluding the leading company's stock price information in investors' investment decisions, investors worry more about their future cash flow risks. Therefore, the results provide support for hypothesis 1 . That is, including the stock price information of the leading company can lower the leverage effect and reduce the impact of selling news on investors.

\subsection{Experimental Design and Estimation Method}

Two main research methods in behavioral finance are Structural Equation Modeling (SEM) and experimental methods. As the former requires a carefully designed questionnaire and a large scale of survey to find a suitable theoretical model, this study adopts the experimental method and uses a simulation program in MultiCharts to develop a model for following the leading company's stock prices.

Specifically, for the Formosa Plastics Group, the leading company of model 1 is Formosa Advanced Technologies and the leading company of model 2 is Nan Ya Printed Circuit Board. Data 1 is the price of individual stocks; Data2 is the price of 0050; Data 3 is the stock price of leading company (i.e., Formosa Advanced Technologies for model 1 and Nan Ya Printed Circuit Board for model 2). ${ }^{6}$ As for the Far Eastern Group, the leading company of model 1 is U-Ming Marine and the leading company of model 2 is Far Eastern Department Stores. Similarly, Data1 is the price of individual stocks; Data2 is the price of 0050; Data 3 is the stock price of leading company (i.e., U-Ming Marine for model 1 and Far Eastern Department Stores for model 2).

Then, this study follows the method in Williams (1999) adds in filters and adopts the RSI technical trading strategy in Lan et al. $(2014 ; 2017)$ which is based on the closing price and the breakthrough by the 20-day moving average. Specifically, a "system buy" requires the following three conditions to be met and they are: (1) today's closing price of Data2 is higher than 20-day moving average price of Data2; (2) today's closing price of Data1 is higher than the 20-day moving average price of Data1; and (3) the RSI of today's stock prices is higher than the best buying point's RSI. On the contrary, a "system sell” requires three conditions to be met and they are: (1) today's closing price of Data2 is lower than 20-day moving average price of Data2; (2) today's closing price of 
Data 1 is lower than the 20-day moving average price of Data1; and (3) the RSI of today's stock prices is lower than the best selling point's RSI. This study uses the optimized trading program to find the optimal number of days in moving average. The position is closed out if the profit is greater than 500 points or the loss is greater than 100 points. Based on the results from simulated experiments, we can test for hypothesis 2 ; that is, incorporating the leading company of the business group in the technical analysis can enhance the trading performance in the stock market. This, at the same time, indirectly proves the existence of herding behavior.

\section{Data}

Based on the classifications provided in TEJ database, nine publicly listed companies of the Formosa Plastics Group (including Formosa Plastics (1301), Na Ya Plastics (1303), Formosa Petrochemical (6505), Formosa Chemicals \& Fibre (1326), Formosa Taffeta (1434), Nanya Technology (2408), Nan Ya Printed Circuit Board (8046) and Formosa Advanced Technologies (8131) and Formosa Sumco Technology (3532)) and Taiwan 50 ETF (0050) are included as filters. That is, this study has 10 sample set of time series data. The sample period covers from 10 December 2007 to 10 August 2017; that is, a total of 2393 daily sample data. ${ }^{7}$

As for the Far Eastern Group, eight publicly listed companies (including Asia Cement (1102), Far Eastern New Century (1402), Everest Textile (1460), Oriental Union Chemical (1710), U-Ming Marine (2606), Far Eastern International Bank (2845), Far Eastern Department Stores (2903), Far EsTone Telecommunications (4904)) and Taiwan 50 ETF (0050) are included as filters. That is, nine sample sets of time series data are investigated. The sample period covers from 29 October 2007, the peak before financial tsunami, to 10 August 2017; that is, a total of 2423 daily sample data. All the data mentioned above are obtained from TEJ database and MultiCharts daily stock price database.

To ensure that integrity of the model, the experiments are carried out in two stages. For the Formosa Plastics Group, the first stage covers the period from 2007.12.10 2014.12.29 (which is the end of QE). The second stage covers the period from 2007.12.10 2017.8.10. As for the Far Eastern Group, only the starting date differs, where the sample period starts on 29 October 2007. The method of testing the Far Eastern Group is the same as the Formosa Plastics Group. The parameters used in the second stage of simulation are based on the optimal parameters from the first stage. The trading cost in simulated models is assumed to be about $1 \%$ of the 200 -day moving average of the underlying company's stock prices. Transaction fees and slippage are not considered in the experiments.

\section{Empirical Results of the Formosa Plastics Group 5.1. Granger Causality Test of Formosa Plastics Group}

\subsubsection{Unit Root Test of Model Variables}

To ensure the validity of empirical results, we need to ensure the stationarity of the series by testing the VAR model and choosing the minimal AIC value. The results of Formosa Plastics Group are as follows. Including the intercept and trend $(2.7044(0))$ does not reject the null hypothesis. That is, the variables are not stationary, have fat tails that are often observed in financial data, and have autocorrelations. Therefore, $\mathrm{I}(\mathrm{O})$ is not stationary. After taking a difference $(.46 .4714(0))$, the null hypothesis is rejected and $\mathrm{I}(1)$ is stationary (Table 1). Therefore, we can proceed with VAR and Johansen co-integration test.

Table-1. Unit root test of VAR model variables of Formosa Plastics Group

\begin{tabular}{l|l|l}
\hline & Original Value & First Order Difference \\
\hline Variables / Model & Intercept and Trend & Intercept and Trend \\
\hline A 1301 & $-2.7044(0)$ & $-46.4714(0)^{*}$ \\
\hline A1303 & $-3.4905(1)^{* *}$ & $-44.9050(0)^{*}$ \\
\hline A 326 & $-2.5880(1)$ & $-45.5030(0)^{*}$ \\
\hline A 1434 & $-3.6787(0)^{* *}$ & $-50.9778(0)^{*}$ \\
\hline A2408 & $-2.3178(0)$ & $-47.7780(0)^{*}$ \\
\hline A3532 & $-3.2634(1)^{* * *}$ & $-44.5537(0)^{*}$ \\
\hline A6505 & $-3.3609(0)^{* * *}$ & $-50.3610(0)^{*}$ \\
\hline A8046 & $-4.2184(0) * *$ & $-47.3754(0)^{*}$ \\
A8131 & $-2.8096(1)$ & $-47.5000(0)^{*}$ \\
A50 & $-2.8347(0)$ & $-48.7114(0)^{*}$ \\
\hline Note: $* * *, * * *$ shows significance level at $1 \%, 5 \%$ and $10 \%$. The number inside the bracket represents the number of lagging
\end{tabular}
periods. (0) shows that when the lag period is 0 , it has the minimal AIC. Sample code is as provided in Section 4.

\subsubsection{Lag Period Test of the Model}

In order to proceed with the VAR model estimation, lagging periods must be tested first. The results show that the AIC and FPE of the Formosa Plastics Group are at their minimum when the data are lagged 8 periods (Table 2). This study also tests the maximum likelihood proposed by Johansen and Juselius (1990) to examine the cointegration relationships between multi-variables. The model has five co-integration equations (Table 3). Therefore, we can conduct the Granger causality test. 
Table-2. Lag period estimation of Formosa Plastics Group's VAR model

\begin{tabular}{l|l|l|l|l|l|l}
\hline Lag & LogL & LR & FPE & AIC & SC & HQ \\
\hline 0 & -61799.68 & NA & $1.29 \mathrm{E}+10$ & 51.65874 & 51.68289 & 51.66753 \\
\hline 1 & -34712.05 & 53926.22 & 2.063684 & 29.10326 & $29.36897^{*}$ & 29.19994 \\
\hline 7 & -33026.5 & 2440.603 & 0.833097 & 28.19599 & 29.911 & $28.82000^{*}$ \\
\hline 8 & -32926.22 & 193.7792 & $0.832969^{*}$ & $28.19575^{*}$ & 30.15231 & 28.90766 \\
\hline 11 & -32689.69 & $126.8364^{*}$ & 0.878709 & 28.2488 & 30.93001 & 29.22437 \\
\hline
\end{tabular}

Table-3. Co-integration estimation results of Johansen model for Formosa Plastics Group

\begin{tabular}{l|l|l|l|l|l|l|l}
\hline & \multicolumn{3}{|c|}{ Trace } & & & \multicolumn{1}{c|}{ Max-Eigen } & \\
\hline No. of CE(s) & Eigenvalue & Statistic & Critical Value(0.05) & Prob. & Statistic & Critical Value(0.05) & Prob. \\
\hline None $*$ & 0.1982 & 1955.79 & 219.40 & 0 & 528.53 & 61.03 & 0.0001 \\
\hline At most 1* & 0.1573 & 1427.26 & 179.51 & 0 & 409.64 & 54.97 & 0.0001 \\
\hline At most 2* & 0.1373 & 1017.62 & 143.67 & 0.0001 & 353.32 & 48.88 & \\
\hline At most 3* & 0.1278 & 664.30 & 111.78 & 0.0001 & 327.14 & 42.77 & 0.0001 \\
\hline At most 4* & 0.1125 & 337.16 & 83.94 & 0 & 285.54 & 36.63 & 0.0001 \\
\hline At most 5 & 0.0096 & 51.62 & 60.06 & 0.2101 & 23.00 & 30.44 & 0.0001 \\
\hline
\end{tabular}

\subsubsection{Granger Causality Test}

As the relationships between variables are not clear based on economic theories, in this case we can use the VAR model to examine the dynamic relationships between variables. Specifically, we assume that the variables are related to each other and regress the variables in the current period with their lag periods. To investigate the investment behavior of Formosa Plastics Group, we include the trading information of nine companies and Taiwan 50 ETF in the VAR model and conduct Granger causality test. The results show that when lagging eight periods, Formosa Advanced Technologies ( 8 times), Nan Ya Printed Circuit Board (5 times) and Taiwan 50 ETF (4 times) are the top three that have the highest number of Granger cause of other companies. In other words, the investment behavior of the other eight companies of the Formosa Plastics Group all refuse to reject the data of Taiwan 50 ETF and Formosa Advanced Technologies. Therefore, the data of Taiwan 50 ETF and Formosa Advanced Technologies can be treated as endogeneous variables (Table 4). The data of Taiwan 50 ETF and Formosa Advanced Technologies are the Granger cause of other companies and cause herding trading behavior in other companies.

Table-4. Granger causality test of Formosa Plastics Group

\begin{tabular}{|c|c|c|c|c|c|c|c|c|c|c|c|}
\hline \multicolumn{3}{|c|}{ Dependent variable: D(A1301) } & \multicolumn{3}{|c|}{ Dependent variable: A1434 } & \multicolumn{3}{|c|}{ Dependent variable: A6505 } & \multicolumn{3}{|c|}{ Dependent variable: $\mathrm{D}$ (P50) } \\
\hline Excluded & Chi-sq & Prob. & Excluded & Chi-sq & Prob. & Excluded & Chi-sq & Prob. & Excluded & Chi-sq & Prob. \\
\hline A1303 & 19.34 & 0.01 & $\mathrm{D}(\mathrm{A} 1301)$ & 10.68 & 0.22 & $\mathrm{D}(\mathrm{A} 1301)$ & 6.79 & 0.56 & $\mathrm{D}(\mathrm{A} 1301)$ & 14.23 & 0.08 \\
\hline $\mathrm{D}(\mathrm{A} 1326)$ & 26.43 & 0.00 & A1303 & 20.98 & 0.01 & A1303 & 12.62 & 0.13 & A1303 & 11.35 & 0.18 \\
\hline A1434 & 14.14 & 0.08 & $\mathrm{D}(\mathrm{A} 1326)$ & 5.44 & 0.71 & $\mathrm{D}(\mathrm{A} 1326)$ & 8.41 & 0.39 & $\mathrm{D}(\mathrm{A} 1326)$ & 5.19 & 0.74 \\
\hline$\overline{\mathrm{D}(\mathrm{A} 2408)}$ & 2.65 & 0.95 & $\mathrm{D}(\mathrm{A} 2408)$ & 7.11 & 0.52 & A1434 & 7.93 & 0.44 & A1434 & 16.39 & 0.04 \\
\hline A3532 & 18.61 & 0.02 & A3532 & 11.01 & 0.20 & $\mathrm{D}(\mathrm{A} 2408)$ & 4.28 & 0.83 & $\mathrm{D}(\mathrm{A} 2408)$ & 1.71 & 0.99 \\
\hline A6505 & 13.05 & 0.11 & A6505 & 10.31 & 0.24 & A3532 & 9.44 & 0.31 & A3532 & 38.55 & 0.00 \\
\hline A8046 & 21.89 & 0.01 & A8046 & 11.13 & 0.19 & A8046 & 5.20 & 0.74 & A6505 & 4.54 & 0.81 \\
\hline $\mathrm{D}(\mathrm{A} 8131)$ & 20.93 & 0.01 & $\mathrm{D}(\mathrm{A} 8131)$ & 14.87 & 0.06 & $\mathrm{D}(\mathrm{A} 8131)$ & 20.16 & 0.01 & A 8046 & 12.45 & 0.13 \\
\hline $\mathrm{D}$ (P50) & 14.04 & 0.08 & $\mathrm{D}$ (P50) & 22.66 & 0.00 & $\mathrm{D}$ (P5O) & 7.79 & 0.45 & $\mathrm{D}(\mathrm{A} 8131)$ & 22.96 & 0.00 \\
\hline All & 140.86 & 0.00 & All & 118.33 & 0.00 & All & 102.73 & 0.01 & All & 130.16 & 0.00 \\
\hline \multicolumn{3}{|c|}{ Dependent variable: A1303 } & \multicolumn{3}{|c|}{ Dependent variable: $\mathrm{D}(\mathrm{A} 2408)$} & \multicolumn{3}{|c|}{ Dependent variable: A8046 } & \multicolumn{3}{|c|}{ Dependent variable: $\mathrm{D}(\mathrm{A} 8131)$} \\
\hline Excluded & Chi-sq & Prob. & Excluded & Chi-sq & Prob. & Excluded & Chi-sq & Prob. & Excluded & Chi-sq & Prob. \\
\hline$\overline{\mathrm{D}(\mathrm{A} 1301)}$ & 10.49 & 0.23 & $\mathrm{D}(\mathrm{A} 1301)$ & 4.20 & 0.84 & $\mathrm{D}(\mathrm{A} 1301)$ & 17.84 & 0.02 & $\mathrm{D}(\mathrm{A} 1301)$ & 19.14 & 0.01 \\
\hline $\mathrm{D}(\mathrm{A} 1326)$ & 9.95 & 0.27 & A1303 & 6.96 & 0.54 & A1303 & 12.15 & 0.14 & A1303 & 6.57 & 0.58 \\
\hline A 1434 & 9.78 & 0.28 & $\mathrm{D}(\mathrm{A} 1326)$ & 1.36 & 0.99 & $\mathrm{D}(\mathrm{A} 1326)$ & 9.45 & 0.31 & $\mathrm{D}(\mathrm{A} 1326)$ & 5.87 & 0.66 \\
\hline$\overline{\mathrm{D}(\mathrm{A} 2408)}$ & 2.78 & 0.95 & A 1434 & 8.81 & 0.36 & A1434 & 8.28 & 0.41 & A 1434 & 10.08 & 0.26 \\
\hline A3532 & 13.20 & 0.11 & A3532 & 1.48 & 0.99 & $\mathrm{D}(\mathrm{A} 2408)$ & 2.44 & 0.96 & $\mathrm{D}(\mathrm{A} 2408)$ & 1.10 & 1.00 \\
\hline A6505 & 11.30 & 0.19 & A6505 & 1.13 & 1.00 & A3532 & 82.27 & 0.00 & A3532 & 33.59 & 0.00 \\
\hline A8046 & 14.31 & 0.07 & A8046 & 7.05 & 0.53 & A6505 & 7.48 & 0.49 & A6505 & 4.31 & 0.83 \\
\hline $\mathrm{D}(\mathrm{A} 8131)$ & 23.09 & 0.00 & $\mathrm{D}(\mathrm{A} 8131)$ & 4.97 & 0.76 & $\mathrm{D}(\mathrm{A} 8131)$ & 25.88 & 0.00 & A8046 & 19.40 & 0.01 \\
\hline $\mathrm{D}(\mathrm{P} 50)$ & 18.24 & 0.02 & $\mathrm{D}(\mathrm{P} 5 \mathrm{O})$ & 4.03 & 0.85 & $\mathrm{D}$ (P50) & 15.02 & 0.06 & $\mathrm{D}(\mathrm{P} 50)$ & 21.89 & 0.01 \\
\hline All & 124.28 & 0.00 & All & 38.79 & 1.00 & All & 185.72 & 0.00 & All & 137.11 & 0.00 \\
\hline
\end{tabular}

\begin{tabular}{l|l|l|}
\hline Dependent variable: D(A1326) & Dependent variable: A3532 \\
\hline
\end{tabular}

\begin{tabular}{l|l|l|l|l|l}
\hline Excluded & Chi-sq & Prob. & Excluded & Chi-sq & Prob. \\
\hline $\mathrm{D}(\mathrm{A} 1301)$ & 6.67 & 0.57 & $\mathrm{D}(\mathrm{A} 1301)$ & 9.15 & 0.33 \\
\hline $\mathrm{A} 1303$ & 12.98 & 0.11 & $\mathrm{~A} 1303$ & 11.62 & 0.17 \\
\hline $\mathrm{A} 1434$ & 12.34 & 0.14 & $\mathrm{D}(\mathrm{A} 1326)$ & 4.47 & 0.81 \\
\hline $\mathrm{D}(\mathrm{A} 2408)$ & 7.09 & 0.53 & $\mathrm{~A} 1434$ & 11.87 & 0.16 \\
\hline $\mathrm{A} 3532$ & 9.66 & 0.29 & $\mathrm{D}(\mathrm{A} 2408)$ & 5.08 & 0.75 \\
\hline $\mathrm{A} 6505$ & 16.45 & 0.04 & $\mathrm{~A} 6505$ & 9.96 & 0.27 \\
\hline $\mathrm{A} 8046$ & 16.10 & 0.04 & $\mathrm{~A} 8046$ & 54.20 & 0.00 \\
\hline $\mathrm{D}(\mathrm{A} 8131)$ & 18.33 & 0.02 & $\mathrm{D}(\mathrm{A} 8131)$ & 3841.38 & 0.00 \\
\hline $\mathrm{D}(\mathrm{P} 50)$ & 10.24 & 0.25 & $\mathrm{D}(\mathrm{P} 50)$ & 70.84 & 0.00 \\
\hline All & 112.94 & 0.00 & $\mathrm{All}$ & 4186.39 & 0.00 \\
\hline
\end{tabular}

Note: Prob. means probability. Chi-sq is the $\chi^{2}$ statistics. Sample code is the same as Table 1. D means taking the first difference. 


\subsection{Granger Causality Test of Na Ya Plastic, Taiwan 50 ETF and Formosa Advanced} Technologies

\subsubsection{Lag Period Test}

In this section, we use Na Ya Plastic, Taiwan 50 ETF and Formosa Advanced Technologies as examples and carry out the VAR model estimation. We need to first test the lagging period and the results show that the AIC and FPE of Na Ya Plastic, Taiwan 50 ETF and Formosa Advanced Technologies are at their minimum when lagging two periods (Table 5). Therefore, this model is estimated using a lag period of two. Also, based on the maximum likelihood estimation proposed by Johansen and Juselius (1990) we test the co-integration relationship between multi-variables. The model has two co-integrated equations (Table 6).

Table-5. Lag period estimation of VAR model of Na Ya Plastic, Taiwan 50 ETF and Formosa Advanced Technologies

\begin{tabular}{l|l|l|l|l|l|l}
\hline Lag & LogL & LR & FPE & AIC & SC & HQ \\
\hline 0 & -13756.69 & NA & 19.81256 & 11.49995 & 11.50719 & 11.50258 \\
\hline 1 & -7645.846 & 12201.25 & 0.120823 & 6.400206 & $6.429192^{*}$ & 6.410753 \\
\hline 2 & -7622.395 & 46.76492 & $0.119373^{*}$ & $6.388128^{*}$ & 6.438854 & $6.406585^{*}$ \\
\hline 6 & -7592.430 & $18.20995^{*}$ & 0.119977 & 6.393171 & 6.530855 & 6.443268 \\
\hline
\end{tabular}

Table-6. Co-integration estimation results of Johansen model for Na Ya Plastic, Taiwan 50 ETF and Formosa Advanced Technologies

\begin{tabular}{l|l|l|l|l|l|l|l}
\hline & & Trace & & & Max-Eigen & \\
\hline No. of CE(s) & Eigenvalue & Statistic & Critical Value(0.05) & Prob. & Statistic & Critical Value(0.05) & Prob. \\
\hline None ${ }^{*}$ & 0.4051 & 2252.31 & 24.28 & 1 & 1242.90 & 17.80 & 1 \\
\hline At most 1 & 0.3440 & 1009.41 & 12.32 & 0.0001 & 1008.88 & 11.22 & 0.0001 \\
\hline At most 2 & 0.0002 & 0.54 & 4.13 & 0.5261 & 0.54 & 4.13 & 0.5261 \\
\hline
\end{tabular}

\subsubsection{Granger Causality Test}

Three variables, Na Ya Plastic, Taiwan 50 ETF and Formosa Advanced Technologies, are included in the VAR model and conducted the Granger causality test. Results show that when lagging two periods, apart from Taiwan 50 ETF which is not the Granger cause of $\mathrm{Na}$ Ya Plastic, Na Ya Plastic, Taiwan 50 ETF and Formosa Advanced Technologies are Granger cause of each other and can be treated as endogenous variables (Table 7). In other words, the three variables refuse to reject the data of each other and we can proceed with the investment simulation in the next stage.

Table-7. Granger causality relationships between Na Ya Plastic, Taiwan 50 ETF and Formosa Advanced Technologies

\begin{tabular}{l|l|l|l}
\hline & A1303 & P50 & A8131 \\
\hline A1303 & - & $\begin{array}{l}2.1692 \\
(0.338)\end{array}$ & $\begin{array}{l}8.8867 \\
(0.0118)\end{array}$ \\
& & - & 13.1406 \\
P50 & 11.6966 & & $(0.0014)$ \\
& $(0.0029)$ & - \\
\hline A8131 & 4.4544 & 26.7587 & \\
& $(0.0178)$ & $(0.0000)$ & \\
\hline
\end{tabular}

\subsection{Estimation of EGARCH Model's Coefficient and News Impact Response}

\subsubsection{Estimation Results of EGARCH model (excluding Formosa Advanced Technologies)}

The values of $\alpha$ (0.0679), $\beta$ (0.9941), $\gamma$ (0.0452) of the model (excluding Formosa Advanced Technologies) are all significant at the $1 \%$ level and are all positive. This suggests the existence of asymmetric volatility. The volatility caused by good news (0.1131) is greater than the impact of bad news on the logarithm of conditional variance (0.022 times) (Table 8).

Table-8. Estimation Results of EGARCH model (excluding Formosa Advanced Technologies)

\begin{tabular}{l|l|l|l|l}
\hline Variable & Coefficient & Std. Error & z-Statistic & Prob. \\
\hline A1303 & 0.000142 & 0.001566 & 0.090982 & 0.9275 \\
\hline $\mathrm{D}(\mathrm{A} 1326)$ & 0.503892 & 0.010579 & 47.63353 & 0 \\
\hline $\mathrm{A} 1434$ & -0.00074 & 0.003351 & -0.2206 & 0.8254 \\
\hline $\mathrm{D}(\mathrm{A} 2408)$ & -0.01361 & 0.014484 & -0.93948 & 0.3475 \\
\hline $\mathrm{A} 3532$ & -0.00103 & 0.000507 & -2.03818 & 0.0415 \\
\hline $\mathrm{A} 6505$ & 0.00073 & 0.000785 & 0.929408 & 0.3527 \\
\hline $\mathrm{A} 8046$ & 0.000188 & 0.000287 & 0.655265 & 0.5123 \\
\hline $\mathrm{D}(\mathrm{P} 50)$ & 0.47616 & 0.023113 & 20.60105 & 0 \\
\hline Variance Equation & \multicolumn{5}{|l}{} & \\
\hline $\mathrm{C}(9)$ & -0.05348 & 0.006881 & -7.77239 & 0 \\
\hline $\mathrm{C}(10)$ & 0.067979 & 0.008613 & 7.892741 & 0 \\
\hline $\mathrm{C}(11)$ & 0.045297 & 0.0076 & 5.959912 & 0 \\
\hline $\mathrm{C}(12)$ & 0.994168 & 0.001492 & 666.2372 & 0 \\
\hline R-squared & 0.526442 & Akaike info criterion & 2.325313 \\
\hline Log likelihood & -2770.24 & Schwarz criterion & 2.354299
\end{tabular}

Then, this study draws the news impact curve based on the EGARCH model (excluding Formosa Advanced Technologies) (Figure 1). In order to see the difference between Figure 1 and Figure 2 more easily, the figure includes kernel density at the frame of the figures. The kernel density is a non-parametric way to estimate the 
probability density function of a random variable and can be presented by a non-continuous bar graph. The kernel density of series $X$ at point $x$ can be estimated by:

$$
f(x)=\frac{1}{N h} \sum_{i=1}^{N} K\left(\frac{x-X_{i}}{h}\right)
$$

where $N$ is the sample size, $h$ is the width based on Silverman (1986) and $k$ is the kernel function. The Epanechnikov density form is given by:

$$
\frac{3}{4}\left(1-\mu^{2}\right) I(|\mu| \leq 1)
$$

where $I$ is the index function; when $|\mu| \leq 1,1$ is chosen, or otherwise 0 .

Figure 1 shows that when the news impact is less than 0 (i.e., when encountering negative news), the curve is flatter. In contrast, the news impact curve is steeper when having positive news. This is likely due to the integration strategy and company policy within the Formosa Plastics Group, which strengthen the function of the business group's headquarter. ${ }^{8}$ Therefore, the effect of negative news on stock prices is weakened.

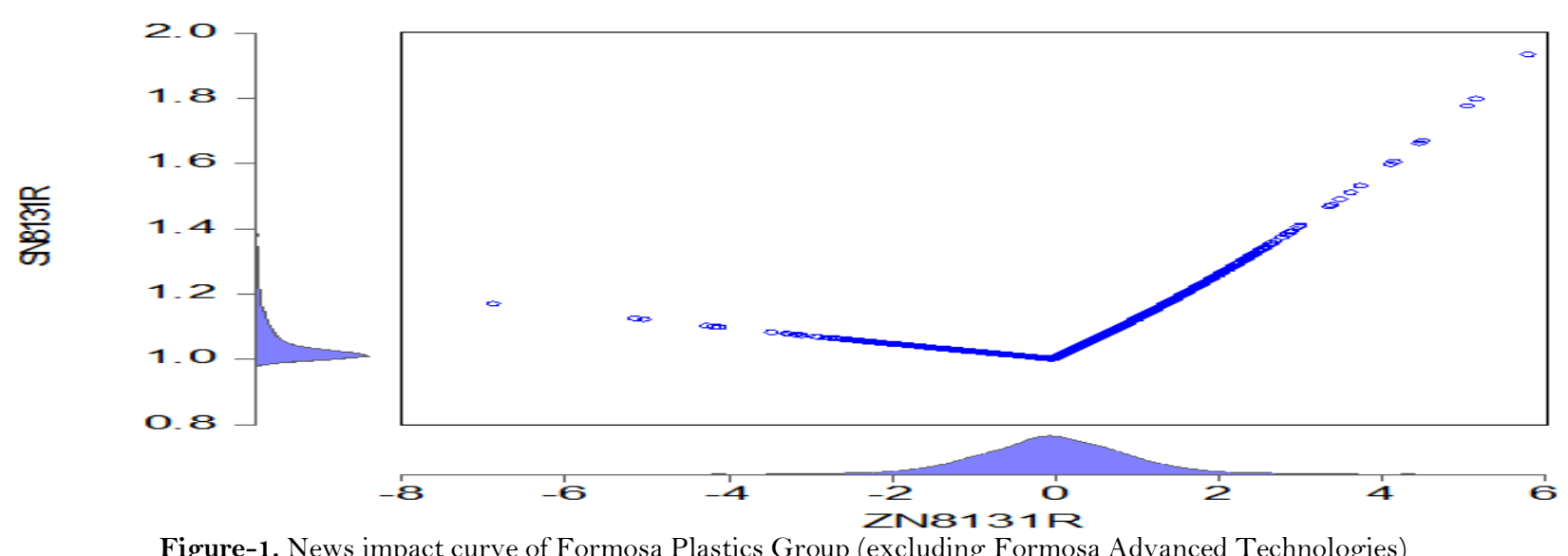

Figure-1. News impact curve of Formosa Plastics Group (excluding Formosa Advanced Technologies)

\subsubsection{Estimation Results of EGARCH Model (including Formosa Advanced Technologies)}

The coefficients of this model (including Formosa Advanced Technologies) are all significant at the $1 \%$ level without adding any restrictions. The values of $\alpha(0.0661), \beta$ (0.9943) and $\gamma(0.0460)$ are all positive. The value of $\alpha$ $+\gamma$ is proportional to its sensitivity. When having good news, the impact on the logarithm of conditional variance can be presented as: $0.0661+0.0460=0.1121$ times; when having bad news, the impact on the logarithm of conditional variance can be presented as: $0.0661+0.0460^{*}(-1)=0.0201$ times. This suggests that investors do not have greater psychological reactions to bad news (Table 9).

\begin{tabular}{|c|c|c|c|c|}
\hline Variable & Coefficient & Std. Error & z-Statistic & Prob. \\
\hline A1303 & $4.47 \mathrm{E}-\mathrm{O} 5$ & 0.001562 & 0.028636 & 0.9772 \\
\hline $\mathrm{D}(\mathrm{A} 1326)$ & 0.504051 & 0.010627 & 47.42908 & 0 \\
\hline A1434 & -0.00063 & 0.0033 & -0.18953 & 0.8497 \\
\hline $\mathrm{D}(\mathrm{A} 2408)$ & -0.01376 & 0.014311 & -0.96156 & 0.3363 \\
\hline A3532 & -0.00104 & 0.000495 & -2.09259 & 0.0364 \\
\hline A6505 & 0.000754 & 0.000763 & 0.987339 & 0.3235 \\
\hline A8046 & 0.000203 & 0.00028 & 0.723959 & 0.4691 \\
\hline $\mathrm{D}(\mathrm{A} 8131)$ & 0.018598 & 0.022756 & 0.817257 & 0.4138 \\
\hline $\mathrm{D}(\mathrm{P} 50)$ & 0.465813 & 0.025222 & 18.46823 & $\mathrm{O}$ \\
\hline \multicolumn{5}{|c|}{ Variance Equation } \\
\hline $\mathrm{C}(10)$ & -0.05208 & 0.00679 & -7.67018 & 0 \\
\hline $\mathrm{C}(11)$ & 0.066172 & 0.008509 & 7.7765 & $\mathrm{O}$ \\
\hline $\mathrm{C}(12)$ & 0.046068 & 0.007513 & 6.131406 & 0 \\
\hline $\mathrm{C}(13)$ & 0.994309 & 0.00147 & 676.2493 & 0 \\
\hline R-squared & 0.526034 & \multicolumn{2}{|c|}{ Akaike info criterion } & 2.325885 \\
\hline Log likelihood & -2769.92 & \multicolumn{2}{|c|}{ Schwarz criterion } & 2.357287 \\
\hline
\end{tabular}

Table-9. Estimation results of EGARCH model (including Formosa Advanced Technologies)

Based on the EGARCH model results, including Formosa Advanced Technologies, the news impact curve is drawn and shown in Figure 2. The Figure also shows that when the news impact is less than 0 (i.e., when encountering negative news), the curve is flatter. In contrast, the news impact curve is steeper when having positive news. However, compared with Figure 1 (which excludes Formosa Advanced Technologies), the curve is even flatter when Formosa Advanced Technologies is included. This suggests that including Formosa Advanced Technologies can lower the risks and the $\beta$ of the model (0.99) is close to 1 ; that is, it is slowly stabilize. Therefore, the effect of negative news on stock prices is weakened. 


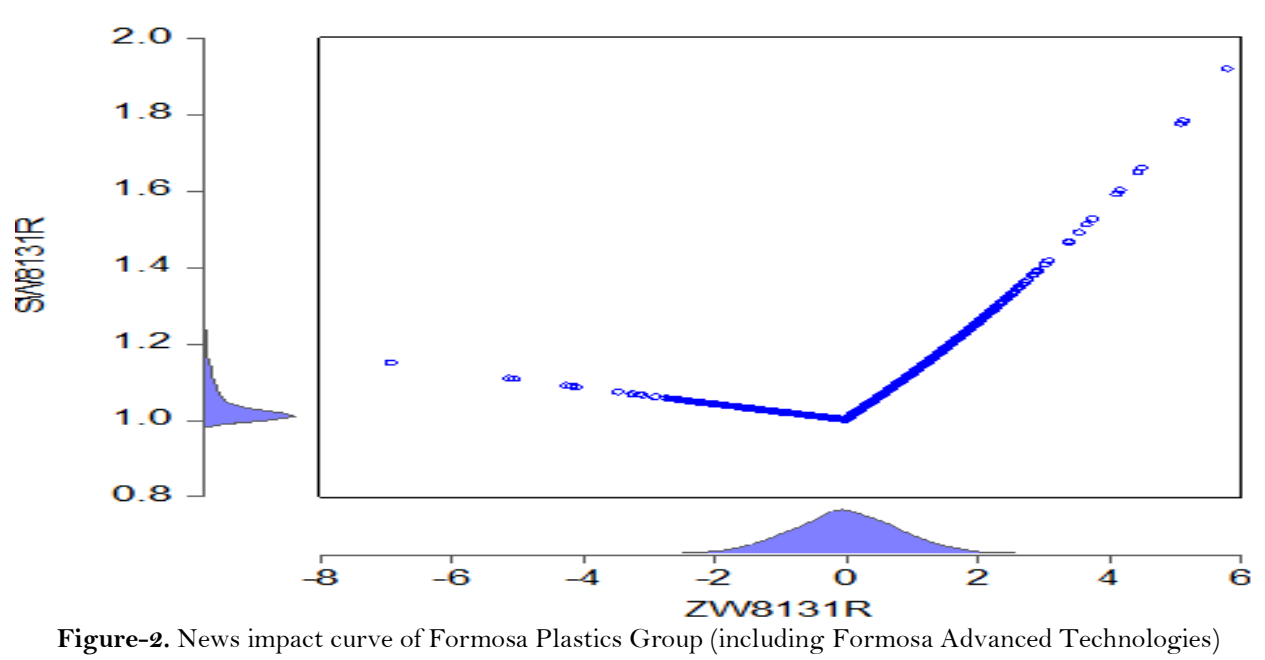

As the $\gamma$ coefficients are positive no matter the leading company's stock prices are included or not, very little difference in figures can be observed in figures. Therefore, this study further test for the difference in $\gamma$ coefficients. The $t$ statistic is 3.52 (Appendix 2), suggesting a significant difference in $\gamma$ coefficients of Formosa Advanced Technologies. Investor sentiment is calmer when Formosa Advanced Technologies is included.

\subsection{Comparison of Formosa Plastics Group's Investment Performance}

The model adopts the stock prices of leading company, Taiwan 50 ETF and other stocks. That is, Data1 is the price of individual stocks; Data2 is the price of 0050 ETF; Data3 is the price of leading company, where Formosa Advanced Technologies is used in model 1 and Nan Ya Printed Circuit Board is used in model 2. The results show that in model 1, the returns increase in the second stage for six companies (Table 10-1). If the investment portfolio includes the eight companies in the Formosa Plastics Group, the investment is profitable. The profits increase from $\$ 353.66$ in the first stage to $\$ 357.86$ in the second stage, showing an increase of $12.49 \%$. The results show that this program trading is profitable. However, the performance of Formosa Plastics Group is worse than the whole market by $16.01 \%$. This is probably because the peak in Taiwan's stock market is mainly caused by iphone's supply chain companies.

\begin{tabular}{|c|c|c|c|c|c|c|c|c|}
\hline \multirow[b]{2}{*}{$\begin{array}{l}\text { Company } \\
\text { Code }\end{array}$} & \multicolumn{3}{|c|}{ 2007.12.10-2014.12.29 } & \multicolumn{3}{|c|}{$2007.12 .10-2017.8 .10$} & \multirow[b]{2}{*}{$\begin{array}{l}\text { Changes } \\
\text { in Profits }\end{array}$} & \multirow[b]{2}{*}{$\begin{array}{l}\text { Total } \\
\text { Profits }\end{array}$} \\
\hline & Net Profit & $\begin{array}{l}\text { No. } \\
\text { Transactions }\end{array}$ & $\begin{array}{l}\text { Winning } \\
\text { Probability }\end{array}$ & Net Profit & $\begin{array}{|ll|}\text { No. } & \text { of } \\
\text { Transactions }\end{array}$ & $\begin{array}{l}\text { Winning } \\
\text { Probability }\end{array}$ & & \\
\hline A1301 & 26.56 & 1 & -100 & 35.88 & 3 & 100 & 9.32 & \multirow{8}{*}{44.2} \\
\hline A1303 & 25 & 1 & 100 & 25 & 1 & 100 & 0 & \\
\hline A6505 & 14.1 & 5 & 80 & 27.64 & 9 & 64 & 13.54 & \\
\hline A1326 & 48.36 & 4 & 75 & 48.36 & 4 & 75 & $\mathrm{O}$ & \\
\hline A 1434 & 14.34 & 1 & 100 & 14.68 & 2 & 100 & 0.34 & \\
\hline A2408 & 44.6 & 4 & 100 & 59.7 & 6 & 100 & 15.1 & \\
\hline A8406 & 128.7 & 5 & 80 & 132.07 & 6 & 83 & 3.37 & \\
\hline A3532 & 52.0 & 6 & 83 & 54.53 & 8 & 75 & 2.53 & \\
\hline
\end{tabular}

Note: The first stage covers the period 2007.12.10 2014.12.29. The second stage covers the period 2007.12.10 2017.8.10. Changes in profits cover the period 2014.10.29 2017.8.10.

The results of model 2 show that four companies in model 2 increase the returns in the second stage. The portfolio formed by eight companies in the Formosa Plastics Group is also profitable (Table 10-2). The profit in the first stage is $\$ 192.76$ and increases by $\$ 28.35(14.7 \%)$ in the second stage. The results are better than that in model 1. However, when the profit of $\$ 353.66$ in model 1 is used as the denominator, the increase is only $8.01 \%$, which is worse than the $12.49 \%$ in model 1. Therefore, the model with Formosa Advanced Technologies as the leading company is better than the model with Nan Ya Printed Circuit Board as the leading company.

The results of Formosa Plastics Group also provide support for hypothesis 1 and 2. That is, including the stock price data of the leading company can lower the impact of negative news. In addition, after choosing the leading company of the business group, we can use technical analysis to enhance the trading performance in the stock market and we indirectly prove the existence of herding behavior.

Table-10.2. Investment returns of model 2, including Nan Ya Printed Circuit Board as the leading company (Unit: \$, times, \%)

\begin{tabular}{|c|c|c|c|c|c|c|c|c|}
\hline \multirow{2}{*}{$\begin{array}{l}\text { Company } \\
\text { Code }\end{array}$} & \multicolumn{3}{|c|}{$2007.12 .10-2014.10 .29$} & \multicolumn{3}{|c|}{ 2007.12.10-2017.8.10 } & \multirow{2}{*}{$\begin{array}{l}\text { Changes } \\
\text { in Profits }\end{array}$} & \multirow{2}{*}{$\begin{array}{l}\text { Total } \\
\text { Profits }\end{array}$} \\
\hline & Net Profit & $\left|\begin{array}{ll}\text { No. } & \text { of } \\
\text { Transactions }\end{array}\right|$ & $\begin{array}{l}\text { Winning } \\
\text { Probability }\end{array}$ & Net Profit & $\begin{array}{ll}\text { No. } & \text { of } \\
\text { Transactions }\end{array}$ & $\begin{array}{l}\text { Winning } \\
\text { Probability }\end{array}$ & & \\
\hline A1301 & 26.81 & 1 & 100 & 48.67 & 2 & 100 & 21.86 & \multirow{8}{*}{28.35} \\
\hline A 1303 & 27.46 & 1 & 100 & 27.46 & 1 & 100 & $\mathrm{O}$ & \\
\hline A6505 & 11.9 & 1 & 100 & 11.9 & 1 & 100 & $\mathrm{O}$ & \\
\hline A1326 & 34.54 & 6 & 83 & 40.92 & 8 & 75 & 6.38 & \\
\hline A 1434 & 12.23 & 1 & 100 & 12.23 & 1 & 100 & 0 & \\
\hline $\mathrm{A} 2408$ & 27.98 & 2 & 100 & 28.68 & 3 & 100 & 0.7 & \\
\hline A8131 & 24.79 & 4 & 75 & 26.55 & 5 & 80 & 1.76 & \\
\hline A3532 & 27.05 & 6 & 83 & 24.7 & 11 & 63 & -2.35 & \\
\hline
\end{tabular}




\section{Empirical Results of the Far Eastern Group}

\subsection{Granger Causality Test of the Far Eastern Group}

\subsubsection{Unit Root Test of Model Variables of Far Eastern Group}

To ensure the validity of empirical results, we check the stationarity of the series by testing the VAR model and choosing the minimal AIC value. Taking Asia Cement as an example, the results reject the null hypothesis when the intercept and trend $(2.9108(0))$ are included. That is, the variable is stationary. Therefore, we can proceed with VAR and Granger causality test. Other variables are found to have fat tails and autocorrelation. That is, I(1) is not stationary. After taking a difference, the null hypotheses are rejected (Table 11) and I(0) is stationary.

\begin{tabular}{l|l|l} 
& \multicolumn{2}{c}{ Table-1 1. Unit root test of VAR model variables of Far Eastern Group } \\
\hline & Original Value & First Order Difference \\
\hline Variables / Model & Intercept and Trend & Intercept and Trend \\
\hline A1102 & $-2.9108(0)^{* *}$ & $-30.8949(2)^{*}$ \\
\hline A1402 & $-2.9712(0)$ & $-37.5003(0)^{*}$ \\
\hline A1460 & $-3.2906(0)^{* *}$ & $-46.5832(0)^{*}$ \\
\hline A1710 & $-2.3558(0)$ & $-47.3465(0)^{*}$ \\
\hline A2606 & $-3.3800(1)^{* *}$ & $-43.2681(0)^{*}$ \\
\hline A2845 & $-2.2999(0)$ & $-47.5449(0)^{*}$ \\
\hline A2903 & $-2.3971(1)$ & $-40.2399(0)^{*}$ \\
\hline A4904 & $-2.7583(0)$ & $-36.7305(1)^{*}$ \\
\hline A50 & $-2.8347(0)$ & $-48.7114(0)^{*}$ \\
\hline Note: $*{ }^{*} *{ }^{*} * *$ shows significance level at $1 \%, 5 \%$ and $10 \%$. The number inside the bracket represents the number of lagging \\
periods. (0) shows that when the lag period is 0, it has the minimal AIC. Sample code is as provided in Section 4.
\end{tabular}

\subsubsection{Lag-Period Co-integration Test of Far Eastern Group's VAR Model}

Before proceeding with the VAR model estimation, lag periods need be tested. The results show that the AIC and FPE of the Far Eastern Group are at their minimum when the data are lagged two periods (Table 12). Therefore, the model is tested with two lagging periods. This study also tests the maximum likelihood proposed by Johansen and Juselius (1990) to examine the co-integration relationships between multi-variables. The model has five co-integration equations (Table 13). Therefore, we can conduct the Granger causality test.

Table-12. Lag period estimation of Far Eastern Group's VAR model

\begin{tabular}{l|l|l|l|l|l|l}
\hline Lag & LogL & LR & FPE & AIC & SC & HQ \\
\hline 0 & -40212.81 & NA & 2399.206 & 33.32379 & 33.34537 & 33.33164 \\
\hline 1 & -16202.17 & 47822.35 & $5.89 \mathrm{E}-06$ & 13.49807 & $13.71390^{*}$ & $13.57657^{*}$ \\
\hline 2 & -16048.74 & 304.4466 & $5.54 \mathrm{e}-06^{*}$ & $13.43806^{*}$ & 13.84814 & 13.5872 \\
\hline 8 & -15648.49 & $141.4467^{*}$ & $5.95 \mathrm{E}-06$ & 13.50911 & 15.08466 & 14.08213 \\
\hline
\end{tabular}

Table-13. Johansen co-integration test results

\begin{tabular}{|c|c|c|c|c|c|c|c|}
\hline & & Trace & & & Max-Eigen & & \\
\hline No. of CE(s) & Eigenvalue & Statistic & Critical Value(0.05) & Prob. & Statistic & Critical Value(0.05) & Prob. \\
\hline None * & 0.4489 & 5824.35 & 179.51 & $\mathrm{O}$ & 1442.06 & 54.97 & 1.00 \\
\hline At most $1 *$ & 0.3966 & 4382.29 & 143.67 & 0 & 1222.33 & 48.88 & 1.00 \\
\hline At most $2^{*}$ & 0.3769 & 3159.96 & 111.78 & 1 & 1144.92 & 42.77 & 1.00 \\
\hline At most $3 *$ & 0.3561 & 2015.04 & 83.94 & 1 & 1065.23 & 36.63 & 1.00 \\
\hline At most $4^{*}$ & 0.3151 & 949.81 & 60.06 & 0.0001 & 915.82 & 30.44 & 0.00 \\
\hline At most 5 & 0.0087 & 33.98 & 40.17 & 0.1826 & 21.20 & 24.16 & 0.12 \\
\hline
\end{tabular}

Note: * means below the $5 \%$ level and rejects $\mathrm{H}$

\subsubsection{Granger Causality Test of the Far Eastern Group}

In order to examine the investment behavior of Far Eastern Group, we include the trading information of eight companies and Taiwan 50 ETF in the VAR model and conduct Granger causality test. The results show that when lagging two periods, U-Ming Marine (2606) (5times), Taiwan 50 ETF and Far Eastern Department Stores (2903) (4times) have the highest and second highest number of Granger causes. In other words, the investment behavior of the other eight companies of the Far Eastern Group all refuse to reject the data of Taiwan 50 ETF and U-Ming Marine. That is, they are treated as endogeneous variables (Table 14). Therefore, the data of Taiwan 50 ETF and U-Ming Marine are the Granger cause of other companies and cause herding trading behavior in other companies.

\subsection{Granger Causality Test of Asia Cement, Taiwan 50 ETF, and U-Ming Marine}

\subsubsection{Lag Period Test}

In this section, we use Asia Cement, Taiwan 50 ETF and U-Ming Marine as examples to carry out the VAR model estimation. We need to first test the lagging periods. The results show that the AIC, FPE and LR of Asia Cement, Taiwan 50 ETF and U-Ming Marine are at their minimum when lagging 10 periods (Table 15). Therefore, this model is estimated using a lag period of 10. Also, based the maximum likelihood estimation proposed by Johansen and Juselius (1990) we test the co-integration relationship between multi-variables. The model has one co-integrated equations (Table 16). 
Table-14. Granger causality test of Far Eastern Group

\begin{tabular}{|c|c|c|c|c|c|c|c|c|}
\hline \multicolumn{3}{|c|}{ Dependent variable: P2606 } & \multicolumn{3}{|c|}{ Dependent variable: $\mathrm{D}(\mathrm{P} 1402)$} & \multicolumn{3}{|c|}{ Dependent variable: $\mathrm{D}(\mathrm{P} 2903$} \\
\hline Excluded & Chi-sq & Prob. & Excluded & Chi-sq & Prob. & Excluded & Chi-sq & Prob. \\
\hline$\overline{\mathrm{P} 1102}$ & 4.55 & 0.10 & $\mathrm{P} 2606$ & 4.77 & 0.09 & $\mathrm{P} 2606$ & 17.28 & 0.00 \\
\hline P1460 & 2.22 & 0.33 & $\mathrm{P} 1102$ & 0.76 & 0.68 & P1102 & 13.08 & 0.00 \\
\hline $\mathrm{P} 50$ & 7.59 & 0.02 & $\mathrm{P} 1460$ & 2.85 & 0.24 & P1460 & 0.76 & 0.69 \\
\hline $\mathrm{D}(\mathrm{P} 1402)$ & 4.10 & 0.13 & $\mathrm{P} 50$ & 9.67 & 0.01 & $\mathrm{P} 50$ & 3.41 & 0.18 \\
\hline $\mathrm{D}(\mathrm{P} 1710)$ & 0.67 & 0.71 & $\mathrm{D}(\mathrm{P} 1710)$ & 2.94 & 0.23 & $\mathrm{D}(\mathrm{P} 1402)$ & 34.79 & 0.00 \\
\hline $\mathrm{D}(\mathrm{P} 2845)$ & 8.11 & 0.02 & $\mathrm{D}(\mathrm{P} 2845)$ & 2.42 & 0.30 & $\mathrm{D}(\mathrm{P} 1710)$ & 0.17 & 0.92 \\
\hline $\mathrm{D}(\mathrm{P} 2903)$ & 3.11 & 0.21 & $\mathrm{D}(\mathrm{P} 2903)$ & 28.97 & 0.00 & $\mathrm{D}(\mathrm{P} 2845)$ & 1.82 & 0.40 \\
\hline $\mathrm{D}(\mathrm{P} 4904)$ & 1.36 & 0.51 & $\mathrm{D}(\mathrm{P} 4904)$ & 6.50 & 0.04 & $\mathrm{D}(\mathrm{P} 4904)$ & 3.35 & 0.19 \\
\hline All & 32.28 & 0.01 & All & 64.06 & 0.00 & All & 206.51 & 0.00 \\
\hline \multicolumn{3}{|c|}{ Dependent variable: $\mathrm{P} 1102$} & \multicolumn{3}{|c|}{ Dependent variable: $\mathrm{D}(\mathrm{P} 1710)$} & \multicolumn{3}{|c|}{ Dependent variable: $\mathrm{D}(\mathrm{P} 4904)$} \\
\hline Excluded & Chi-sq & Prob. & Excluded & Chi-sq & Prob. & Excluded & Chi-sq & Prob. \\
\hline $\mathrm{P} 2606$ & 37.31 & 0.00 & $\mathrm{P} 2606$ & 15.54 & 0.00 & $\mathrm{P} 2606$ & 0.30 & 0.86 \\
\hline P1460 & 1.20 & 0.55 & $\mathrm{P} 1102$ & 2.08 & 0.35 & P1102 & 1.30 & 0.52 \\
\hline $\mathrm{P} 50$ & 1.79 & 0.41 & $\mathrm{P} 1460$ & 1.27 & 0.53 & $\mathrm{P} 1460$ & 1.24 & 0.54 \\
\hline $\mathrm{D}(\mathrm{P} 1402)$ & 27.23 & 0.00 & P50 & 3.83 & 0.15 & $\mathrm{P} 50$ & 3.98 & 0.14 \\
\hline $\mathrm{D}(\mathrm{P} 1710)$ & 5.45 & 0.07 & $\mathrm{D}(\mathrm{P} 1402)$ & 0.14 & 0.93 & $\mathrm{D}(\mathrm{P} 1402)$ & 0.49 & 0.78 \\
\hline $\mathrm{D}(\mathrm{P} 2845)$ & 1.37 & 0.50 & $\mathrm{D}\left(\mathrm{P}_{2845)}\right.$ & 1.72 & 0.42 & $\mathrm{D}(\mathrm{P} 1710)$ & 0.14 & 0.93 \\
\hline $\mathrm{D}(\mathrm{P} 2903)$ & 18.80 & 0.00 & $\mathrm{D}\left(\mathrm{P}_{2903)}\right.$ & 2.64 & 0.27 & $\mathrm{D}(\mathrm{P} 2845)$ & 4.64 & 0.10 \\
\hline $\mathrm{D}(\mathrm{P} 4904)$ & 2.07 & 0.36 & $\mathrm{D}(\mathrm{P} 4904)$ & 0.41 & 0.81 & $\mathrm{D}(\mathrm{P} 2903)$ & 0.32 & 0.85 \\
\hline All & 107.58 & 0.00 & All & 45.11 & 0.00 & All & 20.74 & 0.19 \\
\hline \multicolumn{3}{|c|}{ Dependent variable: $\mathrm{P} 1460$} & \multicolumn{3}{|c|}{ Dependent variable: $\mathrm{D}(\mathrm{P} 2845)$} & \multicolumn{3}{|c|}{ Dependent variable: P5O } \\
\hline Excluded & Chi-sq & Prob. & Excluded & Chi-sq & Prob. & Excluded & Chi-sq & Prob. \\
\hline P2606 & 5.12 & 0.08 & $\mathrm{P}_{2606}$ & 2.30 & 0.32 & $\mathrm{P}_{2606}$ & 0.59 & 0.74 \\
\hline $\mathrm{P} 1102$ & 3.76 & 0.15 & $\mathrm{P} 1102$ & 1.55 & 0.46 & P1102 & 1.46 & 0.48 \\
\hline $\mathrm{P} 50$ & 5.51 & 0.06 & $\mathrm{P} 1460$ & 0.31 & 0.86 & P1460 & 1.49 & 0.47 \\
\hline $\mathrm{D}(\mathrm{P} 1402)$ & 0.97 & 0.61 & $\mathrm{P} 50$ & 6.43 & 0.04 & $\mathrm{D}(\mathrm{P} 1402)$ & 10.79 & 0.00 \\
\hline $\mathrm{D}(\mathrm{P} 1710)$ & 1.50 & 0.47 & $\mathrm{D}(\mathrm{P} 1402)$ & 0.18 & 0.91 & $\mathrm{D}(\mathrm{P} 1710)$ & 5.87 & 0.05 \\
\hline $\mathrm{D}(\mathrm{P} 2845)$ & 3.04 & 0.22 & $\mathrm{D}(\mathrm{P} 1710)$ & 4.14 & 0.13 & $\mathrm{D}(\mathrm{P} 2845)$ & 4.33 & 0.12 \\
\hline $\mathrm{D}(\mathrm{P} 2903)$ & 2.06 & 0.36 & $\mathrm{D}\left(\mathrm{P}_{2903)}\right.$ & 11.73 & 0.00 & $\mathrm{D}(\mathrm{P} 2903)$ & 7.91 & 0.02 \\
\hline $\mathrm{D}(\mathrm{P} 4904)$ & 0.94 & 0.62 & $\mathrm{D}(\mathrm{P} 4904)$ & 0.80 & 0.67 & $\mathrm{D}(\mathrm{P} 4904)$ & 1.26 & 0.53 \\
\hline All & 26.89 & 0.04 & All & 46.19 & 0.00 & All & 40.04 & 0.00 \\
\hline
\end{tabular}

Note: Prob. means probability. Chi-sq is the $\chi^{2}$ statistics. Sample code is the same as Table 1. D means taking the first difference.

Table-15. Lag period estimation of VAR model of Asia Cement, Taiwan 50 ETF (P50), and U-Ming Marine

\begin{tabular}{l|l|l|l|l|l|l}
\hline Lag & LogL & LR & FPE & AIC & SC & HQ \\
\hline 1 & -7737.154 & 24911.57 & 0.181921 & 6.809450 & 6.839662 & 6.820471 \\
\hline 2 & -7683.505 & 106.9673 & 0.174922 & 6.770216 & $6.823086^{*}$ & 6.789502 \\
\hline 3 & -7656.867 & 53.04309 & 0.172232 & 6.754716 & 6.830246 & $6.782268^{*}$ \\
\hline 10 & -7587.266 & $21.63717^{*}$ & $0.171236^{*}$ & $6.748916^{*}$ & 6.983057 & 6.834326 \\
\hline 12 & -7575.269 & 14.37891 & 0.172143 & 6.754191 & 7.033650 & 6.856132 \\
\hline
\end{tabular}

Table-16. Johansen co-integration test results

\begin{tabular}{l|l|l|l|l|l|l|l}
\hline & & Trace & & Max-Eigen & & \\
\hline No. of CE(s) & Eigenvalue & Statistic & Critical Value(0.05) & Prob. & Statistic & Critical Value $(0.05)$ & Prob. \\
\hline None * & 0.4489 & 5824.35 & 179.51 & O & 1442.06 & 54.97 & 1.00 \\
\hline At most 1 & 0.3966 & 4382.29 & 143.67 & 0 & 1222.33 & 48.88 & 1.00 \\
\hline
\end{tabular}

\subsubsection{Granger Causality Test}

We include three variables, Asia Cement, Taiwan 50 ETF and U-Ming Marine, in the VAR model and conduct the Granger causality test. The results show that when lagging 10 periods, except that U-Ming Marine is not the Granger cause of Taiwan 50 ETF, all other variables are Granger cause of each other and can be treated as endogenous variables (Table 17). In other words, the three variables refuse to reject the data of each other and we can proceed with the investment simulation in the next stage.

Table-17. Granger Causality Relationships between Asia Cement, Taiwan 50 ETF, and U-Ming Marine

\begin{tabular}{l|l|l|l}
\hline & P1102 & P50 & P2606 \\
\hline P1102 & - & $\begin{array}{l}22.3095 \\
(0.0136)\end{array}$ & $\begin{array}{l}52.0642 \\
(0.0000)\end{array}$ \\
& & - & 12.7971 \\
P50 & 23.1639 & & $(0.2352)$ \\
\hline P2606 & $(0.0102)$ & 36.1488 & - \\
& 43.1905 & $(0.0001)$ & \\
\hline
\end{tabular}

Note: Sample codes are the same as that presented in Table 14

\subsection{Coefficients Estimation of EGARCH Model}

\subsubsection{Estimation Results of EGARCH Model (Excluding U-Ming Marine)}

Using $\log (\mathrm{VAR})$, the values of $\alpha(1.2459)$ and $\beta$ (0.9363) of the model (excluding U-Ming Marine) are both significant at the $1 \%$ level. As for $\gamma(0.0822)$, it is positive and significant at the $10 \%$ level. This shows the existence of asymmetric volatility. The volatility caused by good news (1.3282) is greater than the volatility caused by bad news (1.1637) (Table 18). The news impact curve of Far Eastern Group excluding U-Ming Marine is presented in Figure 3. 
Table-18. Estimation results of EGARCH model (excluding U-Ming Marine)

\begin{tabular}{|c|c|c|c|c|}
\hline Variable & Coefficient & Std. Error & z-Statistic & Prob. \\
\hline LOG(GARCH) & 0.253939 & 0.013727 & 18.49924 & $\mathrm{O}$ \\
\hline $\mathrm{P} 1460$ & -1.37272 & 0.003421 & -401.274 & 0 \\
\hline P50 & 0.855594 & 0.000819 & 1044.124 & $\mathrm{O}$ \\
\hline $\mathrm{D}(\mathrm{P} 1402)$ & -0.01974 & 0.029651 & -0.66584 & 0.5055 \\
\hline $\mathrm{D}(\mathrm{P} 1710)$ & -0.07774 & 0.017068 & -4.55488 & 0 \\
\hline $\mathrm{D}(\mathrm{P} 2845)$ & 0.012349 & 0.037818 & 0.326538 & 0.744 \\
\hline $\mathrm{D}(\mathrm{P} 2903)$ & 0.123528 & 0.024697 & 5.001772 & 0 \\
\hline $\mathrm{D}(\mathrm{P} 4904)$ & -0.01338 & 0.013625 & -0.98203 & 0.3261 \\
\hline \multicolumn{5}{|c|}{ Variance Equation } \\
\hline $\mathrm{C}(9)$ & -1.0055 & 0.039416 & -25.51 & 0 \\
\hline $\mathrm{C}(10)$ & 1.245943 & 0.06153 & 20.24945 & 0 \\
\hline $\mathrm{C}(11)$ & 0.082286 & 0.045586 & 1.805092 & 0.0711 \\
\hline $\mathrm{C}(12)$ & 0.934208 & 0.016346 & 57.15351 & 0 \\
\hline R-squared & -0.11256 & \multicolumn{2}{|c|}{ Akaike info criterion } & 5.347462 \\
\hline Log likelihood & -6463.78 & \multicolumn{2}{|c|}{ Schwarz criterion } & 5.376161 \\
\hline
\end{tabular}

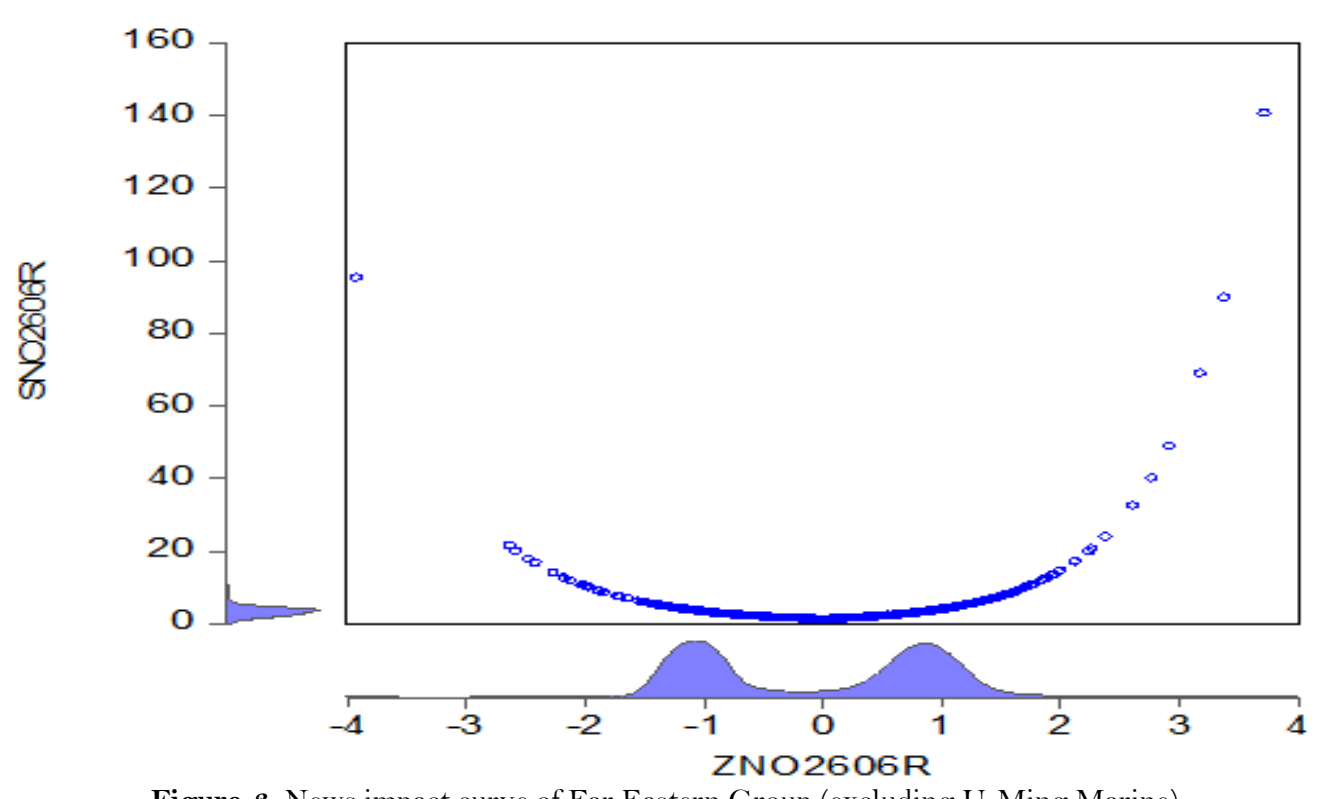

Figure-3. News impact curve of Far Eastern Group (excluding U-Ming Marine)

\subsubsection{Estimation Results of EGARCH Model (Including U-Ming Marine)}

Using the $\log (\mathrm{VAR})$ method, $\alpha(=1.0893), \beta$ (=0.5299), and $\gamma(=-0.1797)$ of this model (including U-Ming Marine) are all significant at the $1 \%$ level. The results shows that due to leverage effect negative news have greater impacts on investors' psychological reactions. The leverage effect of positive news can be presented as: $0.9090=(1.0893-0.1797)$. The leverage effect of negative news can be presented as: $1.2690=1.0893-0.1797 *(-1)$ (Table 19). The $\beta$ of the model including U-Ming Marine is smaller than that of the model excluding U-Ming Marine. This suggests that the model stabilizes more quickly. The news impact curve of the Far Eastern Group, including U-Ming Marine, is presented in Figure 4.

Table-19. Estimation results of EGARCH model (including U-Ming Marine)

\begin{tabular}{|c|c|c|c|c|}
\hline Variable & Coefficient & Std. Error & z-Statistic & Prob. \\
\hline $\mathrm{LOG}(\mathrm{GARCH})$ & -1.99369 & 0.000332 & -6010.5 & 0 \\
\hline P1102 & 1.408301 & $4.92 \mathrm{E}-\mathrm{O} 5$ & 28652.68 & 0 \\
\hline P1460 & -3.35942 & 0.000292 & -11514.9 & 0 \\
\hline $\mathrm{P} 50$ & 0.746751 & $8.08 \mathrm{E}-05$ & 9237.694 & 0 \\
\hline $\mathrm{D}(\mathrm{P} 1402)$ & -0.40108 & 0.002449 & -163.802 & $\mathrm{O}$ \\
\hline $\mathrm{D}(\mathrm{P} 1710)$ & 0.296476 & 0.002707 & 109.5347 & 0 \\
\hline $\mathrm{D}\left(\mathrm{P}_{2845)}\right.$ & -0.15351 & 0.003334 & -46.0395 & 0 \\
\hline $\mathrm{D}(\mathrm{P} 2903)$ & -0.38407 & 0.000308 & -1247.76 & 0 \\
\hline $\mathrm{D}(\mathrm{P} 4904)$ & 0.100932 & 0.003646 & 27.68309 & 0 \\
\hline \multicolumn{5}{|c|}{ Variance Equation } \\
\hline $\mathrm{C}(10)$ & 0.076418 & 0.000226 & 337.6941 & $\mathrm{O}$ \\
\hline $\mathrm{C}(11)$ & 1.089367 & 0.000739 & 1473.486 & 0 \\
\hline $\mathrm{C}(12)$ & -0.17974 & 0.000256 & -701.306 & 0 \\
\hline $\mathrm{C}(13)$ & 0.529939 & 0.000348 & 1521.322 & 0 \\
\hline R-squared & 0.75463 & \multicolumn{2}{|c|}{ Akaike info criterion } & 6.527433 \\
\hline Log likelihood & -7891.72 & \multicolumn{2}{|c|}{ Schwarz criterion } & 6.558523 \\
\hline
\end{tabular}




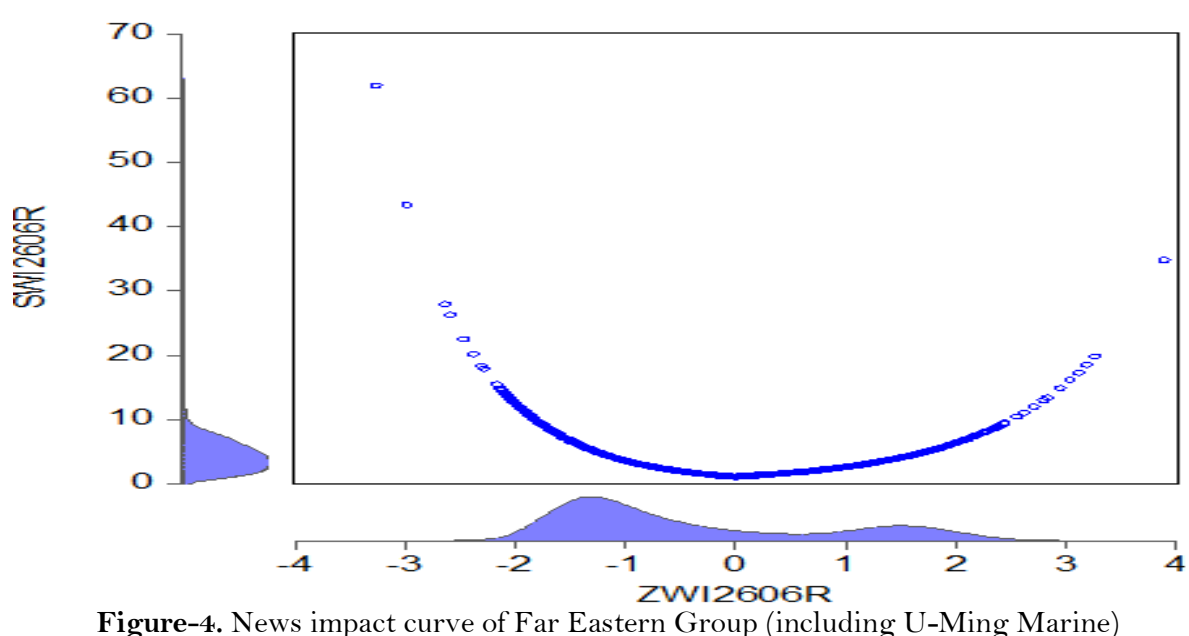

Figure 3 and 4 shows that returns and risks are significantly different depending on weather U-Ming Marine is included. This study also tests for the differences in $\gamma$ coefficients. The $t$ statistic is 105.16, suggesting significant differences in $\gamma$. The results show investor sentiment is calmer when excluding U-Ming Marine.

\subsection{Comparison of Far Eastern Group's Investment Performance}

The model adopts the stock prices of leading company, Taiwan 50 ETF and other stocks. That is, Data1 is the price of individual stocks; Data2 is the price of 0050 ETF; Data3 is the price of leading company, where U-Ming Marine is used in model 1 and Far Eastern Department Stores is used in model 2.

The results show that in model 1, only two companies have an increase in investment returns in the second stage. If the investment portfolio includes the eight companies in Far Eastern Group, the investment is profitable (Table 20-1). The profit in the first stage is $\$ 132.18$ but it decreases to $\$ 129.41$ in the second stage, showing a fall of $0.0209 \%$. Therefore, this program trading is not profitable.

Table-20.1. Investment returns of model 1, including U-Ming Marine as the leading company (Unit: \$, times, \%)

\begin{tabular}{|c|c|c|c|c|c|c|c|c|}
\hline \multirow{2}{*}{$\begin{array}{l}\text { Company } \\
\text { Code }\end{array}$} & \multicolumn{3}{|c|}{ 2007.10.29-2014.10.29 } & \multicolumn{3}{|c|}{ 2007.10.29-2017.8.10 } & \multirow{2}{*}{$\begin{array}{l}\text { Changes } \\
\text { in Profits }\end{array}$} & \multirow{2}{*}{$\begin{array}{l}\text { Total } \\
\text { Profits }\end{array}$} \\
\hline & Net Profit & $\begin{array}{l}\text { No. } \\
\text { Transactions }\end{array}$ & $\begin{array}{ll}\text { of } & \text { Winning } \\
\text { Probability }\end{array}$ & Net Profit & $\begin{array}{l}\text { No. of } \\
\text { Transactions }\end{array}$ & $\begin{array}{l}\text { Winning } \\
\text { Probability }\end{array}$ & & \\
\hline $\mathrm{A} 1102$ & 17.7 & 7 & 100 & 13.99 & 7 & 85 & -3.71 & \multirow{7}{*}{-2.77} \\
\hline $\mathrm{A} 1402$ & 18.12 & 4 & 100 & 19.7 & 5 & 100 & 1.58 & \\
\hline A1460 & 12.24 & 3 & 100 & 13.13 & 4 & 100 & 0.89 & \\
\hline A1710 & 21.35 & 15 & 66 & 20.2 & 20 & 55 & -1.15 & \\
\hline A2606 & - & - & - & - & - & - & $\mathrm{O}$ & \\
\hline A2845 & 4.18 & 11 & 72 & 3.8 & 13 & 61 & -0.38 & \\
\hline A2903 & 28.56 & 4 & 100 & 28.56 & 4 & 100 & 0 & \\
\hline A4904 & 30.03 & 2 & 100 & 30.03 & 2 & 100 & $\mathrm{O}$ & \\
\hline
\end{tabular}

Note: The first stage covers the period 2007.10.29 2014.10.29. The second stage covers the period 2007.10.29 2017.8.10. Changes in profits cover the period 2014.10.29 2017.8.10.

The results of model 2 show that only one company (U-Ming Marine) has an increase in investment returns in the second stage. The portfolio formed by eight companies in the Far Eastern Group as a whole is profitable (Table 20-2). The profit of the investment portfolio in the first stage is $\$ 141.29$ and increases by $\$ 12.07(8.54 \%)$ in the second stage. The findings suggest that model 2 with Far Eastern Department Stores as the leading company is better than model 1 with U-Ming Marine as the leading company. However, when U-Ming Marine is excluded from model 2, it becomes unprofitable. Therefore, the results from Far Eastern Group do not support hypothesis 1 or 2. Specifically, the leading company of the Far Eastern Group is not useful for enhancing the profits. The program trading simulation results also suggest that the diversification strategy of the Far Eastern Group is not as good as the vertical integration strategy of the Formosa Plastics Group. Therefore, when investors are choosing a business group for investing based on herding effect, they should choose carefully. ${ }^{9}$

Table-20.2. Investment returns of model 2, including Far Eastern Department Stores as the leading company (Unit: \$, times, \%)

\begin{tabular}{l|l|l|l|l|l|l|l|l}
\hline \multirow{2}{*}{$\begin{array}{l}\text { Company } \\
\text { Code }\end{array}$} & Net Profit & $\begin{array}{l}\text { No. } \\
\text { Transactions }\end{array}$ & $\begin{array}{l}\text { 2007.10.29-2017.8.10 } \\
\text { Probability }\end{array}$ & Net Profit & $\begin{array}{l}\text { No. } \\
\text { Transactions }\end{array}$ & $\begin{array}{l}\text { Winning } \\
\text { Probability }\end{array}$ & $\begin{array}{l}\text { Changes } \\
\text { in Profits }\end{array}$ & $\begin{array}{l}\text { Total } \\
\text { Profits }\end{array}$ \\
\hline A1 102 & 26.89 & 2 & 100 & 26.89 & 2 & 30 & 0 \\
\hline A1402 & 18.52 & 9 & 66 & 15.83 & 11 & 63 & -2.69 \\
\hline A1460 & 11.11 & 1 & 100 & 11.11 & 1 & 100 & 0 \\
\hline A1710 & 17.36 & 3 & 100 & 17.36 & 3 & 100 & 0 \\
\hline A2606 & 56.83 & 3 & 100 & 72.77 & 4 & 100 & 15.94 \\
\hline A2845 & 4.04 & 6 & 50 & 4.04 & 6 & 50 & 0 \\
\hline A2903 & 0 & - & - & 0 & - & - & 0 \\
\hline A4904 & 6.54 & 2 & 100 & 5.36 & 3 & 66 & -1.18 \\
\hline
\end{tabular}

${ }^{9}$ This study has tried using Taiwan Mid 100 in the model instead of Taiwan 50. However, the sum of $\alpha(1.4335)$ and $\gamma(0.4867)$ is greater than 1, suggesting that this model is not stationary. The program trading simulation also leads to similar conclusion. Therefore, due to page limit, the test results are not provided here. 


\section{Conclusion and Discussion on Investment Strategies}

The aim of this study is to examine the difference in operating performance for two family business groups, Formosa Plastics Group and Far Eastern Group, after the impact of financial tsunami (2007.10.29 2017.08.10). This research helps investors understand the operating model of business groups and learn how to use the herding effect of business groups to enhance their trading performance in financial markets. The results show that for the Formosa Plastics Group, the news impact curve (based on EGARCH model) including the leading company is flatter than when the news impact curve excludes the leading company. In contrast, the news impact curve of the Far Eastern Group is steeper when the leading company is included.

Moreover, when the leading company is include as an endogeneous variable in the model as a filter for the program trading simulation, the net profits for the first stage (2007.10.29 2014.12.29) and the second stage (2007.10.29 2017.08.10) are 12.49\% and $-0.02 \%$, respectively. Therefore, this program trading of the Formosa Plastics Group can lead to trading profits. In sum, business groups that include the leading company have lower risks. It is also beneficial to the stability of the market trading by incorporating the leverage effect of the leading company in business groups. The results show that the Far Eastern Group does not support hypothesis 1 or hypothesis 2. In other words, the leading company of the Far Eastern Group does not have such an effect. The absolute profits and the increment of performance are both lower than that of the Formosa Plastics Group. Therefore, the diversification strategy of the Far Eastern Group is worse than the vertical integration strategy of Formosa Plastics Group. Investors should carefully choose the business group for investment if they are to utilize the herding effect in investment. Due to the space and time limit, future research could study other family business groups in Taiwan and conduct their optimal back testing simulations.

\section{References}

Alanyali, M., H.S. Moat and T. Preis, 2013. Quantifying the relationship between financial news and the stock market. Scientific Reports, 3: 3578. View at Google Scholar | View at Publisher

Bachelier, L., 1900. Theory of speculation. In P. H. Cottner (Ed.), The random character of stock market prices. MIT Press. pp: 17-78.

Baek, J.-S. and J.-K. Kang, 2004. Corporate governance and firm value: Evidence from the Korean financial crisis. Journal of Financial Economics, $71(2):$ 265-313.

Balcilar, M. and R. Demirer, 2015. Effect of global shocks and volatility on herd behavior in an emerging market: Evidence from Borsa Istanbul. Emerging Markets Finance and Trade, 51(1): 140-159. View at Google Scholar | View at Publisher

Banz, R.W., 1981. The relation between return and market value of common stocks. Journal of Financial Economics, 9(1): 3-18. View at Google Scholar | View at Publisher

Ben-David, I., F. Francesco and M. Rabih, 2017. Exchange traded funds. Annual Review of Financial Economics. Retrieved from https://doi.org/10.1146/annurev-financial-1 10716-032538 [Accessed Aug. 11].

Bikhchandani, S., D. Hirshleifer and I. Welch, 1992. A theory of fads, fashion, custom, and cultural change as informational cascades. Journal of Political Economy, 100(5): 992-1026. View at Google Scholar | View at Publisher

Bollerslev, T., 1986. Generalized autoregressive conditional heteroskedasticity. Journal of Economics, 31(3): 307-327. View at Google Scholar | View at Publisher

Cadsby, C.B., 1989. Canadian calendar anomalies and the capital asset pricing model. In: Guimarães R.M.C., Kingsman B.G., Tay lor S.J. (Eds), A reappraisal of the efficiency of financial markets, NATO ASI Series (Series F: Computer and Systems Sciences). Berlin, Heidelberg: Springer, 54.

Christie, W.G. and R.D. Huang, 1995. Following the pied piper: Do individual returns herd around the market? Financial Analys ts Journal, 51(4): 31-37. View at Google Scholar | View at Publisher

Cipriani, M. and A. Guarino, 2014. Estimating a structural model of herd behavior in financial markets. American Economic Review, 104(1): 224-251. View at Google Scholar |View at Publisher

Engle, R.F. and C.W.J. Granger, 1987. Co-integration and error correction: Representation, estimation, and testing. Econometrica, 55(2): 251-276. View at Google Scholar | View at Publisher

Fama, E.F., 1965. The behavior of stock-market prices. Journal of Business, 38(1): 34-105. View at Google Scholar |View at Publisher

Fama, E.F., 1970. Efficient capital markets: A review of theory and empirical work. Journal of Finance, 25(2): 383-417. View at Publisher

Finkelstein, S., 1992. Power in top management teams: Dimensions, measurement, and validation. Academy of Management Journal, 35 (3): 505-538. View at Google Scholar | View at Publisher

Froot, K.A., S.S. David and S.C. Jeremy, 1993. Risk management: Coordinating corporate investment and financing policies. Journal of Finance, 48(5): 1629-1658. View at Google Scholar | View at Publisher

Isard, W., 1951. Interregional and regional input-output analysis: A model of a space-economy. Review of Economics and Statistics, 33(4): 318-328. View at Google Scholar | View at Publisher

Jain, B.A. and O. Kini, 2000. Does the presence of venture capitalists improve the survival profile of IPO firms? Journal of Business Finance and Accounting, 27(9-10): 1139-1183. View at Google Scholar | View at Publisher

Johannisson, B. and M. Huse, 2000. Recruiting outside board members in the small family business: An ideological challenge. Entrepreneurship \& Regional Development, 12(4): 353-378. View at Google Scholar | View at Publisher

Johansen, S., 1991. Estimation and hypothesis testing of cointegration vectors in Gaussian vector autoregressive models. Econometrica, 59(6): 1551-1580. View at Google Scholar | View at Publisher

Johansen, S. and K. Juselius, 1988. Hypothesis Testing for cointegration vectors: With application to the demand for money in Denmark and Finland. Oxford Bulletin of Economics and Statistics, 52(2): 169-210.

Johansen, S. and K. Juselius, 1990. Maximum likelihood estimation and inference on cointegration with applications to demand for money. Oxford Bulletin of Economics and Statistics, 52(2): 169-2 10. View at Google Scholar | View at Publisher

Khanna, T. and Y. Yishay, 2015. Business groups in emerging markets: Paragons or parasites? Review of Economics and Institutions, 6(1): 1-60. View at Google Scholar

Kim, W. and S.-J. Wei, 2002. Foreign portfolio investors before and during a crisis. Journal of International Economics, 56(1): 77-96. View at Google Scholar | View at Publisher

La Porta, R., F. Lopez-de-Silanes and A. Shleifer, 1999. Corporate ownership around the world. Journal of Finance, 54(2): 471-517. View at Google Scholar | View at Publisher

La Porta, R., F. Lopez-de-Silanes, A. Shleifer and R.W. Vishny, 1997. Legal determinants of external finance. Journal of Finance, 52(3): 1131 1150. View at Google Scholar | View at Publisher

La Porta, R., F. Lopez-de-Silanes, A. Shleifer and R.W. Vishny, 1998. Law and finance. Journal of Political Economy, 106(6): 1113-1155. View at Google Scholar

Lakonishok, J., A. Shleifer and R. Vishny, 1992. The impact of institutional trading on stock prices. Journal of Financial Economics, 32(1): 23-43. View at Google Scholar |View at Publisher

Lakonishok, J. and S. Smidt, 1988. Are seasonal anomalies real? A ninety-year perspective. Review of Financial Studies, 1(4): 403-425. View at Google Scholar | View at Publisher

Lan, Y.-W., L. Dan and L. Lu, 2014. How to invest safely in emerging markets during the global financial crisis: A case study of Taiwan. Global Journal of Management and Business Research, 14(4): 29-41.

Lan, Y.-W., D. Lin and L. Lin, 2017. How to invest in stocks of family business groups? case study of WALSIN group in Taiwan. Research in Economics and Management, 2(3): 105-124. View at Google Scholar | View at Publisher 
Maug, E. and N. Naik, 2013. Herding and delegated portfolio management: The impact of relative performance evaluation on asset allocation. IFA Working Paper, No. 223-1996.

Nelson, D.B., 1991. Conditional heteroskedasticity in asset returns: A new approach. Econometrica, 59(2): 347-370. View at Google Scholar | View at Publisher

Palepu, K.G., 1985. Diversification strategy, profit performance and the entropy measure. Strategic Management Journal, 6(3): 239-255. Viezw at Google Scholar | View at Publisher

Samulson, P., 1965. Proof that properly anticipated prices fluctuate randomly. Industrial Management Review, 6(2): 41 -49. View at Google Scholar Scharfstein, D. and J. Stein, 1990. Herd behavior and investment. American Economic Review, 80(3): 465-479. View at Google Scholar

Shiller, R.J., 1979. The volatility of long-term interest rates and expectations models of the term structure. Journal of Political Economy, 87(6): 1190-1219. View at Google Scholar | View at Publisher

Shiller, R.J., 1981. The use of volatility measures in assessing market efficiency. Journal of Finance, 36(2): 291-304. View at Google Scholar |View at Publisher

Shleifer, A. and R.W. Vishny, 1997. A survey of corporate governance. Journal of Finance, 52(2): 737-783. View at Google Scholar | View at Publisher

Silverman, B.W., 1986. Density estimation for statistics and data analysis. N.Y: Chapman and Hall.

Tsai, W.-H., 1997. The political-economic analysis about the development of Taiwan's petrochemical industry (1945-1984). Soochow Journal of Political Science, 8: 157-224.

Wermers, R., 1999. Mutual fund herding and the impact on stock prices. Journal of Finance, 54(2): 581-622. View at Google Scholar | View at Publisher Williams, L., 1999. Long-term secrets to short-term trading. N.Y: John Wiley \& Sons, Inc.

\section{Appendixes}

Appendix-1. The basic information of Formosa Plastics Group and Far Eastern Group Unit: \$, \%, 'OoO million

\begin{tabular}{|c|c|c|c|c|c|c|c|c|c|c|}
\hline $\begin{array}{l}\text { Business } \\
\text { Group }\end{array}$ & Code & Company Name & $\begin{array}{l}\text { Year } \\
\text { Establish }\end{array}$ & $\begin{array}{l}\text { Industry } \\
\text { Classification } \\
\text { (correlation } \\
\text { coefficient*) }\end{array}$ & $\begin{array}{l}\text { Stock } \\
\text { Price } \\
(2017.8 .10)\end{array}$ & $\begin{array}{l}\text { Net } \\
\text { Profits } \\
(2016)\end{array}$ & $\begin{array}{l}\text { EPS } \\
(2016)\end{array}$ & $\begin{array}{l}\text { Market } \\
\text { Value } \\
(7.21)\end{array}$ & \begin{tabular}{|l|} 
Stock \\
holdings \\
$(\%)$
\end{tabular} & $\begin{array}{l}\text { Board } \\
\text { Chairman }\end{array}$ \\
\hline \multirow{9}{*}{$\begin{array}{l}\text { Formosa } \\
\text { Plastics } \\
\text { Group }\end{array}$} & 1301 & Formosa Plastics & 1954 & Plastics (6.78) & 92.6 & 394 & 6.19 & 5825 & 36 & $\begin{array}{l}\text { LIN JIAN } \\
\text { NAN }\end{array}$ \\
\hline & 1303 & $\mathrm{Na}$ Ya Plastics & 1958 & Plastics (6.78) & 75.4 & 484 & 6.16 & 5932 & 43 & $\begin{array}{l}\text { WU JIA } \\
\text { ZHAO }\end{array}$ \\
\hline & 1326 & $\begin{array}{l}\text { Formosa Chemicals } \\
\text { \& Fibre }\end{array}$ & 1965 & Plastics (6.78) & 91.5 & 438 & 7.5 & 5322 & 47 & $\begin{array}{l}\text { WANG } \\
\text { WEN } \\
\text { YUAN }\end{array}$ \\
\hline & 1434 & Formosa Taffeta & 1973 & Textile (6.76) & 29.7 & 35 & 2.07 & 535 & 37 & $\begin{array}{l}\text { WANG } \\
\text { WEN } \\
\text { YUAN }\end{array}$ \\
\hline & 2408 & Nanya Technology & 1995 & Electronic (7.32) & 60.5 & 237 & 8.67 & 1740 & 33 & $\begin{array}{l}\text { WU JIA } \\
\text { ZHAO }\end{array}$ \\
\hline & 3532 & 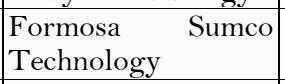 & 1995 & Electronic (7.32) & 88.5 & 7 & 0.94 & 691 & 29 & $\begin{array}{l}\text { LIN JIAN } \\
\text { NAN } \\
\end{array}$ \\
\hline & 6505 & $\begin{array}{l}\text { Formosa } \\
\text { Petrochemical }\end{array}$ & 1992 & $\begin{array}{l}\text { Oil and electricity } \\
(13.16)\end{array}$ & 103.5 & 758 & 7.95 & 10002 & 76 & $\begin{array}{l}\text { CHEN } \\
\text { BAO } \\
\text { LANG }\end{array}$ \\
\hline & 8046 & \begin{tabular}{|l} 
Nan Ya Printed \\
Circuit Board
\end{tabular} & 1997 & Electronic (7.32) & 23.35 & -7 & -1.07 & 158 & 67 & $\begin{array}{l}\text { WU JIA } \\
\text { ZHAO }\end{array}$ \\
\hline & 8131 & $\begin{array}{l}\text { Formosa Advanced } \\
\text { Technologies }\end{array}$ & 1990 & Electronic (7.32) & 27.2 & 10 & 2.31 & 121 & 66 & $\begin{array}{l}\text { WANG } \\
\text { WEN } \\
\text { YUAN }\end{array}$ \\
\hline \multirow{8}{*}{$\begin{array}{l}\text { Far } \\
\text { Eastern } \\
\text { Group }\end{array}$} & 1102 & Asia Cement & 1957 & Cement (14.8) & 26.55 & 39 & 1.26 & 889 & 22 & $\begin{array}{l}\text { XU XU } \\
\text { DONG }\end{array}$ \\
\hline & 1402 & \begin{tabular}{|l|l|}
$\begin{array}{l}\text { Far Eastern New } \\
\text { Century }\end{array}$ \\
\end{tabular} & 1954 & Textile (6.76) & 24.35 & 63 & 1.26 & 1314 & 24 & \begin{tabular}{|lr}
$\mathrm{XU} \quad \mathrm{XU}$ \\
$\mathrm{DONG}$
\end{tabular} \\
\hline & 1460 & Everest Textile & 1988 & Textile (6.76) & 26.1 & 5 & 1.2 & 77 & 25 & XI JIA YI \\
\hline & 1710 & $\begin{array}{ll}\text { Oriental Union } \\
\text { Chemical }\end{array}$ & 1975 & Chemical (7.61) & 26.1 & -6 & -0.63 & 255 & 43 & $\begin{array}{l}\text { XU XU } \\
\text { DONG }\end{array}$ \\
\hline & 2606 & U-Ming Marine & 1968 & Shipping (6.13) & 32.8 & -8 & -1.04 & 270 & 39 & $\begin{array}{l}\text { XU XU } \\
\text { DONG }\end{array}$ \\
\hline & 2845 & $\begin{array}{|lr|}\text { Far } & \text { Eastern } \\
\text { International Bank }\end{array}$ & 1992 & Finance (4.64) & 9.93 & 32 & 1.04 & 309 & 42 & $\begin{array}{l}\text { HOU JIN } \\
\text { YING } \\
\end{array}$ \\
\hline & 2903 & $\begin{array}{|lr|}\text { Far } & \text { Eastern } \\
\text { Department } & \text { Stores }\end{array}$ & 1967 & 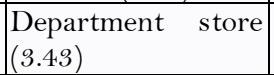 & 15.1 & 11 & 0.81 & 215 & 40 & $\begin{array}{l}\text { XU XU } \\
\text { DONG }\end{array}$ \\
\hline & 4904 & $\begin{array}{|lr|}\text { Far } & \text { EsTone } \\
\text { Telecommunications }\end{array}$ & 1997 & $\begin{array}{l}\text { Telecommunication } \\
(3.62)\end{array}$ & 73.3 & 114 & 3.5 & 2395 & 38 & $\begin{array}{l}\text { XU XU } \\
\text { DONG }\end{array}$ \\
\hline
\end{tabular}

Note: *including forward and backward correlation coefficient (http://www.dgbas.gov.tw/lp.asp?CtNode $=2340 \&$ CtUnit $=1088 \&$ BaseDSD $=7 \& \mathrm{mp}=1$ )

Appendix-2. Test for difference in $\gamma$ coefficients of EGARCH model

\begin{tabular}{|c|c|c|c|c|c|c|}
\hline & \multicolumn{3}{|c|}{ Formosa Plastics Group } & \multicolumn{3}{|c|}{ Far Eastern Group } \\
\hline & $\gamma$ coefficient & Std Dev. & $\mathbf{T}$ & $\gamma$ coefficient & Std Dev. & $\mathbf{T}$ \\
\hline Including leading company & 0.046068 & 0.0075 & \multirow{2}{*}{3.52} & -0.1797 & 0.0003 & \multirow{2}{*}{105.16} \\
\hline Excluding leading company & 0.045297 & 0.0076 & & 0.0823 & 0.0456 & \\
\hline
\end{tabular}

